Atmos. Chem. Phys., 18, 14465-14476, 2018

https://doi.org/10.5194/acp-18-14465-2018

(C) Author(s) 2018. This work is distributed under

the Creative Commons Attribution 4.0 License.

\title{
Atmospheric $\Delta^{17} \mathrm{O}\left(\mathrm{NO}_{3}^{-}\right)$reveals nocturnal chemistry dominates nitrate production in Beijing haze
}

\author{
Pengzhen $\mathrm{He}^{1}$, Zhouqing Xie ${ }^{1,2,3}$, Xiyuan $\mathrm{Chi}^{1}$, Xiawei Yu${ }^{1}$, Shidong Fan ${ }^{1}$, Hui Kang ${ }^{1}$, Cheng Liu ${ }^{1,2,3}$, and \\ Haicong Zhan ${ }^{1}$ \\ ${ }^{1}$ Anhui Province Key Laboratory of Polar Environment and Global Change, School of Earth and Space Sciences, University \\ of Science and Technology of China, Hefei, Anhui 230026, China \\ ${ }^{2}$ Center for Excellence in Urban Atmospheric Environment, Institute of Urban Environment, Chinese Academy of Sciences, \\ Xiamen, Fujian 361021, China \\ ${ }^{3}$ Key Lab of Environmental Optics and Technology, Anhui Institute of Optics and Fine Mechanics, Chinese Academy of \\ Sciences, Hefei, Anhui 230031, China
}

Correspondence: Zhouqing Xie (zqxie@ustc.edu.cn)

Received: 29 March 2018 - Discussion started: 14 May 2018

Revised: 7 September 2018 - Accepted: 24 September 2018 - Published: 10 October 2018

\begin{abstract}
The rapid mass increase of atmospheric nitrate is a critical driving force for the occurrence of fine-particle pollution (referred to as haze hereafter) in Beijing. However, the exact mechanisms for this rapid increase of nitrate mass have not been well constrained from field observations. Here we present the first observations of the oxygen-17 excess of atmospheric nitrate $\left(\Delta^{17} \mathrm{O}\left(\mathrm{NO}_{3}^{-}\right)\right)$collected in Beijing haze to reveal the relative importance of different nitrate formation pathways, and we also present the simultaneously observed $\delta^{15} \mathrm{~N}\left(\mathrm{NO}_{3}^{-}\right)$. During our sampling period, $12 \mathrm{~h}$ averaged mass concentrations of $\mathrm{PM}_{2.5}$ varied from 16 to $323 \mu \mathrm{g} \mathrm{m} \mathrm{m}^{-3}$ with a mean of $(141 \pm 88(1 \mathrm{SD})) \mu \mathrm{g} \mathrm{m}^{-3}$, with nitrate ranging from 0.3 to $106.7 \mu \mathrm{g} \mathrm{m}^{-3}$. The observed $\Delta^{17} \mathrm{O}\left(\mathrm{NO}_{3}^{-}\right)$ranged from $27.5 \%$ o to $33.9 \%$ o with a mean of $(30.6 \pm 1.8) \%$, while $\delta^{15} \mathrm{~N}\left(\mathrm{NO}_{3}^{-}\right)$ranged from $-2.5 \%$ to $19.2 \%$ with a mean of $(7.4 \pm 6.8) \%$ o. $\Delta^{17} \mathrm{O}\left(\mathrm{NO}_{3}^{-}\right)$-constrained calculations suggest nocturnal pathways $\left(\mathrm{N}_{2} \mathrm{O}_{5}+\mathrm{H}_{2} \mathrm{O} / \mathrm{Cl}^{-}\right.$and $\left.\mathrm{NO}_{3}+\mathrm{HC}\right)$ dominated nitrate production during polluted days $\left(\mathrm{PM}_{2.5} \geq\right.$ $75 \mu \mathrm{g} \mathrm{m}^{-3}$ ), with a mean possible fraction of $56-97 \%$. Our results illustrate the potentiality of $\Delta^{17} \mathrm{O}$ in tracing nitrate formation pathways; future modeling work with the constraint of isotope data reported here may further improve our understanding of the nitrogen cycle during haze.
\end{abstract}

\section{Introduction}

Severe and frequent haze pollution has become a crucial threat for the air quality in the megacity of Beijing and the North China Plain in recent years. The high concentrations of $\mathrm{PM}_{2.5}$ (particulate matter with an aerodynamic diameter equal or less than $2.5 \mu \mathrm{m}$ ) during severe haze, of which the hourly average can reach $1000 \mu \mathrm{g} \mathrm{m}^{-3}$ (B. Zheng et al., 2015), are harmful to public health by contributing to cardiovascular morbidity and mortality (Cheng et al., 2013; Brook et al., 2010). Nitrate is an important component of $\mathrm{PM}_{2.5}$, accounting for 1-45\% of $\mathrm{PM}_{2.5}$ mass in Beijing and the North China Plain (Wen et al., 2015; B. Zheng et al., 2015; G. Zheng et al., 2015). The main formation pathways of atmospheric nitrate, defined herein as gas-phase $\mathrm{HNO}_{3}$ plus particulate $\mathrm{NO}_{3}^{-}$, in the urban area are summarized in Fig. 1, which includes (i) $\mathrm{NO}_{2}$ oxidation by $\mathrm{OH}$ radicals in the gas phase, (ii) heterogeneous uptake of $\mathrm{NO}_{2}$ on wet aerosols, (iii) $\mathrm{NO}_{3}$ radicals reacting with hydrocarbon ( $\mathrm{HC}$ ), and (iv) heterogeneous uptake of $\mathrm{N}_{2} \mathrm{O}_{5}$ on wet aerosols and chlorine-containing aerosols. Since $\mathrm{OH}$ radicals are mainly present in the daytime, while $\mathrm{NO}_{3}$ radicals and $\mathrm{N}_{2} \mathrm{O}_{5}$ are mainly present in the nocturnal atmosphere (Brown and Stutz, 2012), $\mathrm{NO}_{2}+\mathrm{OH}$ is usually referred to as the daytime nitrate formation pathway, while $\mathrm{N}_{2} \mathrm{O}_{5}+\mathrm{H}_{2} \mathrm{O} / \mathrm{Cl}^{-}$ and $\mathrm{NO}_{3}+\mathrm{HC}$ are referred to as nocturnal formation pathways (Vicars et al., 2013; Sofen et al., 2014). During haze 


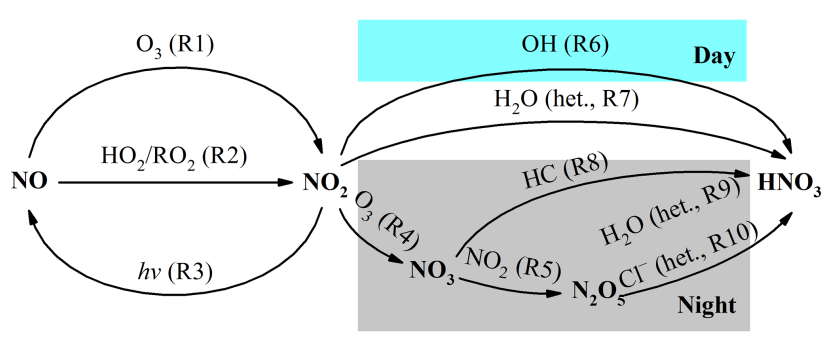

Figure 1. Simplified schematic of the main nitrate formation pathways in urban air; "het." refers to heterogeneous reactions on aerosols.

in Beijing, the mixing ratio of daytime $\mathrm{OH}$ is modeled to be low (G. Zheng et al., 2015; Rao et al., 2016), while a relatively high mixing ratio of nocturnal $\mathrm{N}_{2} \mathrm{O}_{5}$ is observed in several studies (Wang et al., 2017a, b; Li et al., 2018); therefore, nocturnal pathways are suggested to be most responsible for the high concentrations of atmospheric nitrate during haze (Su et al., 2017; Pathak et al., 2009, 2011). In addition, the high $\mathrm{PM}_{2.5}$ concentration and relative humidity during haze in Beijing favor heterogeneous reactions, which renders $\mathrm{NO}_{2}+\mathrm{H}_{2} \mathrm{O}$ a potentially significant pathway for nitrate production (J. Wang et al., 2017; Tong et al., 2015; B. Zheng et al., 2015).

Nitrogen isotopic composition of nitrate $\left(\delta^{15} \mathrm{~N}\left(\mathrm{NO}_{3}^{-}\right)\right.$, wherein $\delta^{15} \mathrm{~N}=\left(R_{\text {sample }} / R_{\text {reference }}-1\right)$, with $R$ representing isotope ratios of ${ }^{15} \mathrm{~N} /{ }^{14} \mathrm{~N}$ in the sample and the reference atmospheric $\mathrm{N}_{2}$ ) is useful in tracing the source of its precursor $\mathrm{NO}_{X}$ (Xiao et al., 2015; Beyn et al., 2014; Fang et al., 2011; Hastings et al., 2013). Anthropogenic sources of $\mathrm{NO}_{X}$ such as coal combustion are generally enriched in $\delta^{15} \mathrm{~N}$, while natural $\mathrm{NO}_{X}$ sources such as soil emissions or lighting typically have a negative or zero $\delta^{15} \mathrm{~N}$ signature (Hoering, 1957; Yu and Elliott, 2017; Felix et al., 2012). Therefore highly positive values of observed $\delta^{15} \mathrm{~N}\left(\mathrm{NO}_{3}^{-}\right)$can be considered as an indicator of anthropogenic combustion (Elliott et al., 2009; Fang et al., 2011), although this judgment may be influenced by isotopic exchange between $\mathrm{NO}$ and $\mathrm{NO}_{2}$ (Freyer et al., 1993; Walters et al., 2016), isotopic fractionations associated with nitrate formation pathways, and isotopic effects occurring during transport, such as deposition of $\mathrm{NO}_{3}^{-}$and $\mathrm{HNO}_{3}$ partitioning between the gas and particle phase (Freyer, 1991; Geng et al., 2014). The oxygen-17 excess $\left(\Delta^{17} \mathrm{O}\right)$ of nitrate, defined as $\Delta^{17} \mathrm{O}=\delta^{17} \mathrm{O}-0.52 \delta^{18} \mathrm{O}$, wherein $\delta^{X} \mathrm{O}=\left(R_{\text {sample }} / R_{\text {reference }}-1\right)$, with $R$ representing isotope ratios of ${ }^{X} \mathrm{O} /{ }^{16} \mathrm{O}$ in the sample and the reference Vienna Standard Mean Ocean Water and $X=17$ or 18 , is particularly useful in reflecting nitrate formation pathways (Michalski et al., 2003). Atmospheric nitrate from nocturnal reaction pathways has higher $\Delta^{17} \mathrm{O}$ than that from daytime $\mathrm{OH}$ oxidation at a given $\Delta^{17} \mathrm{O}\left(\mathrm{NO}_{2}\right)$ (Table 1). And once formed, atmospheric $\Delta^{17} \mathrm{O}\left(\mathrm{NO}_{3}^{-}\right)$cannot be altered by mass-dependent processes such as deposition during trans- port (Brenninkmeijer et al., 2003). Previous studies have shown the utility of atmospheric $\Delta^{17} \mathrm{O}\left(\mathrm{NO}_{3}^{-}\right)$in quantifying the relative importance of various nitrate formation pathways (Alexander et al., 2009; Michalski et al., 2003; Patris et al., 2007; Savarino et al., 2013; Vicars et al., 2013). For example, the $\Delta^{17} \mathrm{O}\left(\mathrm{NO}_{3}^{-}\right)$-constrained box modeling work of Michalski et al. (2003) suggests that more than $90 \%$ of atmospheric nitrate is from nocturnal $\mathrm{N}_{2} \mathrm{O}_{5}+\mathrm{H}_{2} \mathrm{O}$ pathways in winter in La Jolla, California, which is reflected by the highest $\Delta^{17} \mathrm{O}\left(\mathrm{NO}_{3}^{-}\right)$values being observed in winter. In another study, Alexander et al. (2009) use observed $\Delta^{17} \mathrm{O}\left(\mathrm{NO}_{3}^{-}\right)$to constrain a 3-D model and found that the daytime $\mathrm{NO}_{2}+\mathrm{OH}$ pathway dominates global tropospheric nitrate production, with an annual mean contribution of $76 \%$.

Until now, however, field observations of atmospheric $\Delta^{17} \mathrm{O}\left(\mathrm{NO}_{3}^{-}\right)$have not been conducted in north China to constrain the relative importance of different nitrate formation pathways during haze. In this work, we present the first observations of atmospheric $\Delta^{17} \mathrm{O}\left(\mathrm{NO}_{3}^{-}\right)$during Beijing haze from October 2014 to January 2015, and use this observation to examine the importance of nocturnal formation pathways. We also present the signature of simultaneously observed $\delta^{15} \mathrm{~N}\left(\mathrm{NO}_{3}^{-}\right)$.

\section{Materials and methods}

\subsection{Sampling and atmospheric observations}

$\mathrm{PM}_{2.5}$ filter samples were collected at a flow rate of $1.05 \mathrm{~m}^{3} \mathrm{~min}^{-1}$ using a high volume air sampler (model TH1000C II, Tianhong Instruments Co., Ltd, China). The quartz microfiber filter (Whatman Inc., UK) is pre-combusted at $450{ }^{\circ} \mathrm{C}$ for $4 \mathrm{~h}$ before sampling. Our sampling period lasted from October 2014 to January 2015, with the collection interval being $12 \mathrm{~h}(08: 00-20: 00 \mathrm{LT}$ or 20:00-08:00 LT) for each sample. Blank control samples were also collected. The blank was sampled identically to the real sample except that the collection interval was $1 \mathrm{~min}$. Due to the fact that gaseous $\mathrm{HNO}_{3}$ is likely to adsorb onto particulate matter already trapped by the filter material (Vicars et al., 2013), the nitrate species collected is likely to include both particulate nitrate and gaseous $\mathrm{HNO}_{3}$, which is referred to as atmospheric nitrate in previous studies (Vicars et al., 2013; Morin et al., 2009; Michalski et al., 2003) and in this study. The sampling site is at the campus of University of the Chinese Academy of Sciences $\left(40.41^{\circ} \mathrm{N}, 116.68^{\circ} \mathrm{E} ; \sim 20 \mathrm{~m}\right.$ high) in suburban Beijing, about $60 \mathrm{~km}$ northeast of downtown Beijing (Fig. 2), which is a supersite set up by HOPE- $\mathrm{J}^{3} \mathrm{~A}$ (Haze Observation Project Especially for Jing-Jin-Ji Area), with various observations being reported (Zhang et al., 2017; Xu et al., 2016; Chen et al., 2015; Tong et al., 2015; He et al., 2018). Hourly concentrations of surface $\mathrm{PM}_{2.5}, \mathrm{CO}, \mathrm{SO}_{2}, \mathrm{NO}_{2}$, and $\mathrm{O}_{3}$ were observed at Huairou station $\left(40.33^{\circ} \mathrm{N}, 116.63^{\circ} \mathrm{E}\right)$ by Beijing Municipal Environmental Monitoring Center, about 
Table 1. Isotope assumptions of different nitrate formation pathways.

\begin{tabular}{|c|c|c|c|c|}
\hline \multirow{2}{*}{ No. } & \multirow{2}{*}{ Reaction } & \multicolumn{2}{|l|}{$\Delta^{17} \mathrm{O}$ of product } & \multirow{2}{*}{ Reference } \\
\hline & & Expression & Value $(\% o)^{\mathrm{a}}$ & \\
\hline R1 & $\mathrm{NO}+\mathrm{O}_{3} \rightarrow \mathrm{NO}_{2}+\mathrm{O}_{2}$ & $\Delta^{17} \mathrm{O}\left(\mathrm{NO}_{2}\right)=1.18 \times \Delta^{17} \mathrm{O}\left(\mathrm{O}_{3}\right)+6.6 \%$ & 37 & Savarino et al. (2008) \\
\hline $\mathrm{R} 2$ & $\mathrm{NO}+\mathrm{HO}_{2} / \mathrm{RO}_{2} \rightarrow \mathrm{NO}_{2}+\mathrm{OH} / \mathrm{RO}$ & $\Delta^{17} \mathrm{O}\left(\mathrm{NO}_{2}\right)=0.0$ & 0.0 & Sofen et al. (2014) \\
\hline $\mathrm{R} 4$ & $\mathrm{NO}_{2}+\mathrm{O}_{3} \rightarrow \mathrm{NO}_{3}+\mathrm{O}_{2}$ & $\Delta^{17} \mathrm{O}\left(\mathrm{NO}_{3}\right)=\frac{2}{3} \Delta^{17} \mathrm{O}\left(\mathrm{NO}_{2}\right)+\frac{1}{3}\left(1.23 \times \Delta^{17} \mathrm{O}\left(\mathrm{O}_{3}\right)+9.0 \% \circ\right)$ & $25 \alpha+14$ & Berhanu et al. (2012) \\
\hline R5 & $\mathrm{NO}_{2}+\mathrm{NO}_{3} \rightarrow \mathrm{N}_{2} \mathrm{O}_{5}$ & $\Delta^{17} \mathrm{O}\left(\mathrm{N}_{2} \mathrm{O}_{5}\right)=\frac{2}{5} \Delta^{17} \mathrm{O}\left(\mathrm{NO}_{2}\right)+\frac{3}{5} \Delta^{17} \mathrm{O}\left(\mathrm{NO}_{3}\right)$ & $30 \alpha+8$ & Sofen et al. (2014) \\
\hline R6 & $\mathrm{NO}_{2}+\mathrm{OH} \rightarrow \mathrm{HNO}_{3}$ & $\Delta^{17} \mathrm{O}\left(\mathrm{NO}_{3}^{-}\right)=\frac{2}{3} \Delta^{17} \mathrm{O}\left(\mathrm{NO}_{2}\right)$ & $25 \alpha$ & Sofen et al. (2014) \\
\hline R7 & $2 \mathrm{NO}_{2}+\mathrm{H}_{2} \mathrm{O} \rightarrow \mathrm{HNO}_{3}+\mathrm{HNO}_{2}$ & $\Delta^{17} \mathrm{O}\left(\mathrm{NO}_{3}^{-}\right)=\frac{2}{3} \Delta^{17} \mathrm{O}\left(\mathrm{NO}_{2}\right)$ & $25 \alpha$ & $\mathrm{b}$ \\
\hline $\mathrm{R} 8$ & $\mathrm{NO}_{3}+\mathrm{HC} \rightarrow \mathrm{HNO}_{3}+$ products & $\Delta^{17} \mathrm{O}\left(\mathrm{NO}_{3}^{-}\right)=\Delta^{17} \mathrm{O}\left(\mathrm{NO}_{3}\right)$ & $25 \alpha+14$ & Sofen et al. (2014) \\
\hline R9 & $\mathrm{N}_{2} \mathrm{O}_{5}+\mathrm{H}_{2} \mathrm{O} \rightarrow 2 \mathrm{HNO}_{3}$ & $\Delta^{17} \mathrm{O}\left(\mathrm{NO}_{3}^{-}\right)=\frac{5}{6} \Delta^{17} \mathrm{O}\left(\mathrm{N}_{2} \mathrm{O}_{5}\right)$ & $25 \alpha+7$ & Sofen et al. (2014) \\
\hline $\mathrm{R} 10$ & $\mathrm{~N}_{2} \mathrm{O}_{5}+\mathrm{Cl}^{-} \rightarrow \mathrm{HNO}_{3}+\mathrm{ClNO}_{2}$ & $\Delta^{17} \mathrm{O}\left(\mathrm{NO}_{3}^{-}\right)=\Delta^{17} \mathrm{O}\left(\mathrm{NO}_{3}\right)$ & $25 \alpha+14$ & \\
\hline
\end{tabular}

a The values are calculated on assumptions that bulk $\Delta^{17} \mathrm{O}\left(\mathrm{O}_{3}\right)=26 \%$ (Vicars and Savarino, 2014; Ishino et al., 2017) and $\Delta^{17} \mathrm{O}\left(\mathrm{HO}_{2} / \mathrm{RO}_{2}\right)=0 \%$. $\Delta^{17} \mathrm{O}(\mathrm{RO} 2)$ is equal to $0 \%$ in the troposphere (Morin et al., 2011); in contrast, observations suggest $\Delta^{17} \mathrm{O}\left(\mathrm{HO}_{2}\right)=1-2 \%$ (Savarino and Thiemens, 1999). However, the difference in calculated $\Delta^{17} \mathrm{O}\left(\mathrm{NO}_{3}^{-}\right)$between assuming $\Delta^{17} \mathrm{O}\left(\mathrm{HO} \mathrm{O}_{2}\right)=0 \%$ and $\Delta^{17} \mathrm{O}\left(\mathrm{HO}_{2}\right)=2 \%$ is negligible in this study $\left(<0.1 \%\right.$ o). And the assumption that $\Delta^{17} \mathrm{O}\left(\mathrm{HO}_{2}\right)=0 \%$ simplifies calculations and is also consistent with previous studies $(\mathrm{Michalski}$ et al., 2003 ; Alexander et al., 2009; Morin et al., 2008; Kunasek et al., 2008; Sofen et al., 2014). $\alpha$ is the proportion of $\mathrm{O}_{3}$ oxidation in $\mathrm{NO}_{2}$ production rate, calculated by Eq. (3). ${ }^{\mathrm{b}}$ Previous studies suggest that in $\mathrm{R} 7$ one oxygen atom of $\mathrm{NO}_{3}^{-}$is from $\mathrm{H}_{2} \mathrm{O}$ and the other two are from $\mathrm{NO}_{2}$ ( $\mathrm{Li}$ et al., 2010; Cheung et al., 2000; Goodman et al., 1999), which will result in $\Delta^{17} \mathrm{O}\left(\mathrm{NO}_{3}^{-}\right)=2 / 3 \Delta^{17} \mathrm{O}\left(\mathrm{NO}_{2}\right) .{ }^{\mathrm{c}} \mathrm{R}_{4}$ and $\mathrm{R} 5$ suggest that the central oxygen atom of $\mathrm{N}_{2} \mathrm{O}_{5}\left(\mathrm{O}_{2} \mathrm{~N}-\mathrm{O}-\mathrm{NO}_{2}\right)$ is from $\mathrm{NO}_{3}$ radicals $\left(\mathrm{O}-\mathrm{NO}_{2}\right)$, with $\Delta^{17} \mathrm{O}(\%$ o $)=1.23 \times \Delta^{17} \mathrm{O}\left(\mathrm{O}_{3}\right)+9.0 \%$. $\mathrm{R} 10$ is suggested to occur via $\mathrm{O}_{2} \mathrm{~N}-\mathrm{O}-\mathrm{NO} \mathrm{N}_{2}($ aq. $)$ $\rightarrow \mathrm{NO}_{2}^{+}+\mathrm{NO}_{3}^{-}$and the following $\mathrm{NO}_{2}^{+}+\mathrm{Cl}^{-} \rightarrow \mathrm{ClNO}_{2}$ (Bertram and Thornton, 2009), so $\Delta^{17} \mathrm{O}\left(\mathrm{NO}_{3}^{-}\right)=1 / 3\left(1.23 \times \Delta^{17} \mathrm{O}\left(\mathrm{O}_{3}\right)+9.0 \%\right.$ o $)+2 / 3 \Delta^{17} \mathrm{O}\left(\mathrm{NO}_{2}\right)=\Delta^{17} \mathrm{O}\left(\mathrm{NO}_{3}\right)$.

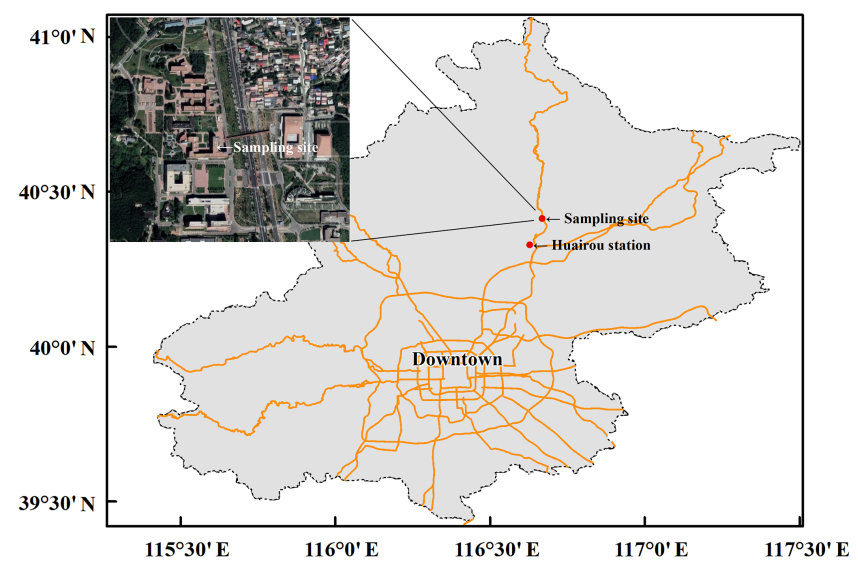

Figure 2. A brief map of the sampling site in Beijing. The map scale of base map is $1: 1250000$. Huairou station is set up by the Beijing Municipal Environmental Monitoring Center, where hourly $\mathrm{PM}_{2.5}$, $\mathrm{SO}_{2}, \mathrm{CO}, \mathrm{NO}_{2}$, and $\mathrm{O}_{3}$ were observed.

$10 \mathrm{~km}$ from our sampling site. Meteorological data including relative humidity $(\mathrm{RH})$ and air temperature $(T)$ were measured by an automatic weather station (model MetPak, Gill Instruments Limited, UK). Time used in the present study is local time $(\mathrm{LT}=\mathrm{UTC}+8)$.

\subsection{Measurements of ions and isotopic ratios}

Ion concentrations of $\mathrm{NO}_{3}^{-}$and $\mathrm{Cl}^{-}$were measured in Anhui Province Key Laboratory of Polar Environment and Global Change in the University of Science and Technology of China. A detailed description of this method can be found in the literature (Ye et al., 2015). Briefly, ions in the $\mathrm{PM}_{2.5}$ filter sample were extracted with Millipore water $(\geq 18 \mathrm{M} \Omega$ ) and insoluble substances in the extract were filtered. Then the ion concentrations were analyzed using an ion chromatograph system (model Dionex ICS-2100, Thermo Fisher Scientific Inc., USA). The measured ion concentrations of blank samples were subtracted when determining the ion concentrations of real samples. Typical analytical precision by our method is better than $10 \%$ relative standard deviation (RSD) (Chen et al., 2016).

$\delta^{15} \mathrm{~N}\left(\mathrm{NO}_{3}^{-}\right)$and $\Delta^{17} \mathrm{O}\left(\mathrm{NO}_{3}^{-}\right)$were measured with a bacterial denitrifier method (Kaiser et al., 2007) in IsoLab at the University of Washington, USA. Briefly, ions in the filter sample were extracted with Millipore water $(\geq 18 \mathrm{M} \Omega$ ) and the insoluble substances were filtered. $\mathrm{NO}_{3}^{-}$in each sample was converted to $\mathrm{N}_{2} \mathrm{O}$ by the denitrifying bacteria, Pseudomonas aureofaciens. Then $\mathrm{N}_{2}$ and $\mathrm{O}_{2}$, which were decomposed from $\mathrm{N}_{2} \mathrm{O}$ in a gold tube at $800^{\circ} \mathrm{C}$, were separated using a gas chromatograph. The isotopic ratios of each gas were then measured by a Finnigan Delta-Plus Advantage isotope ratio mass spectrometer. Masses of 28 and 29 from $\mathrm{N}_{2}$ were measured to determine $\delta^{15} \mathrm{~N}$. Masses of 32, 33, and 34 from $\mathrm{O}_{2}$ were measured to determine $\delta^{17} \mathrm{O}$ and $\delta^{18} \mathrm{O}$, and $\Delta^{17} \mathrm{O}$ was then calculated. We use international nitrate reference materials, USGS34, USGS35, and $\mathrm{IAEANO}_{3}$, for data calibration. The uncertainty $(1 \sigma)$ of $\delta^{15} \mathrm{~N}$ and $\Delta^{17} \mathrm{O}$ measurements in our method is $0.4 \%$ and $0.2 \%$, respectively, based on replicate analysis of the international reference materials. All the samples including blank samples were measured in triplicate to quantify the uncertainty in each sample. The blank was subtracted for each sample by using an isotopic mass balance on the basis of isotopic ratios and concentrations of the blank. To minimize the blank effect, samples with blank concentrations being $>10 \%$ of their concentrations were not analyzed for isotopic ratios. This ruled out 3 of the total 34 samples, all of which are from non-polluted days (NPD, $\mathrm{PM}_{2.5}<75 \mu \mathrm{g} \mathrm{m}^{-3}$ ). In total, isotopic composi- 
tions of 7 samples from NPD and 24 samples from polluted days (PD, $\mathrm{PM}_{2.5} \geq 75 \mu \mathrm{g} \mathrm{m}^{-3}$ ) are reported here.

\subsection{Estimate of different nitrate formation pathways based on $\Delta^{17} \mathrm{O}\left(\mathrm{NO}_{3}^{-}\right)$}

The observed $\Delta^{17} \mathrm{O}\left(\mathrm{NO}_{3}^{-}\right)$is determined by the relative importance of different nitrate formation pathways and the relative importance of $\mathrm{O}_{3}$ oxidation in $\mathrm{NO}_{X}$ cycling as shown in Eq. (1):

$$
\begin{gathered}
\Delta^{17} \mathrm{O}\left(\mathrm{NO}_{3}^{-}\right)=\Delta^{17} \mathrm{O}_{\mathrm{R} 6} \times f_{\mathrm{R} 6}+\Delta^{17} \mathrm{O}_{\mathrm{R} 7} \times f_{\mathrm{R} 7}+\Delta^{17} \mathrm{O}_{\mathrm{R} 8} \\
\times f_{\mathrm{R} 8}+\Delta^{17} \mathrm{O}_{\mathrm{R} 9} \times f_{\mathrm{R} 9}+\Delta^{17} \mathrm{O}_{\mathrm{R} 10} \times f_{\mathrm{R} 10},
\end{gathered}
$$

where $\Delta{ }^{17} \mathrm{O}_{\mathrm{R} 6}, \Delta{ }^{17} \mathrm{O}_{\mathrm{R} 7}, \Delta{ }^{17} \mathrm{O}_{\mathrm{R} 8}, \Delta{ }^{17} \mathrm{O}_{\mathrm{R} 9}$, and $\Delta{ }^{17} \mathrm{O}_{\mathrm{R} 10}$ are, respectively, $\Delta^{17} \mathrm{O}\left(\mathrm{NO}_{3}^{-}\right)$resulting from $\mathrm{NO}_{2}+\mathrm{OH}$, $\mathrm{NO}_{2}+\mathrm{H}_{2} \mathrm{O}, \mathrm{NO}_{3}+\mathrm{HC}, \mathrm{N}_{2} \mathrm{O}_{5}+\mathrm{H}_{2} \mathrm{O}$, and $\mathrm{N}_{2} \mathrm{O}_{5}+\mathrm{Cl}^{-}$pathways (Table 1 ); $f_{\mathrm{R} 6}, f_{\mathrm{R} 7}, f_{\mathrm{R} 8}, f_{\mathrm{R} 9}$, and $f_{\mathrm{R} 10}$ are, respectively, corresponding fractional contributions of the above pathways to nitrate production. Using the $\Delta^{17} \mathrm{O}$ assumptions for different pathways in Table 1 and the definition $f_{\mathrm{R} 6}+f_{\mathrm{R} 7}+f_{\mathrm{R} 8}+f_{\mathrm{R} 9}+f_{\mathrm{R} 10}=1$, Eq. (1) is further expressed as

$$
\begin{aligned}
& \Delta^{17} \mathrm{O}\left(\mathrm{NO}_{3}^{-}\right) / \% 0=25 \alpha f_{\mathrm{R} 6}+25 \alpha f_{\mathrm{R} 7}+(25 \alpha+14) \times f_{\mathrm{R} 8} \\
& \quad+(25 \alpha+7) \times f_{\mathrm{R} 9}+(25 \alpha+14) \times f_{\mathrm{R} 10} \\
& \quad=25 \alpha+14 \times\left(f_{\mathrm{R} 8}+f_{\mathrm{R} 10}\right)+7 f_{\mathrm{R} 9}
\end{aligned}
$$

where $\alpha$ is the proportion of $\mathrm{O}_{3}$ oxidation in $\mathrm{NO}_{2}$ production rate, calculated by Eq. (3):

$\alpha=\frac{k_{\mathrm{R} 1}[\mathrm{NO}]\left[\mathrm{O}_{3}\right]}{k_{\mathrm{R} 1}[\mathrm{NO}]\left[\mathrm{O}_{3}\right]+k_{\mathrm{R} 2 \mathrm{a}}[\mathrm{NO}]\left[\mathrm{HO}_{2}\right]+k_{\mathrm{R} 2 \mathrm{~b}}[\mathrm{NO}]\left[\mathrm{RO}_{2}\right]}$.

In Eq. (3), $k_{\mathrm{R} 1}, k_{\mathrm{R} 2 \mathrm{a}}$, and $k_{\mathrm{R} 2 \mathrm{~b}}$ are, respectively, the reaction rate constants listed in Table 2. To evaluate $\alpha$, we estimated $\mathrm{HO}_{2}$ mixing ratios on the basis of empirical formulas between $\mathrm{HO}_{2}$ and $\mathrm{O}_{3}$ mixing ratios derived from observations in winter (Kanaya et al., 2007); i.e., $\left[\mathrm{HO}_{2}\right] /\left(\mathrm{pmol} \mathrm{mol}^{-1}\right)=$ $\exp \left(5.7747 \times 10^{-2} \times\left[\mathrm{O}_{3}\right] /\left(\mathrm{nmol} \mathrm{mol}^{-1}\right)-1.7227\right)$

during the daytime and $\left[\mathrm{HO}_{2}\right] /\left(\mathrm{pmol} \mathrm{mol}^{-1}\right)=$ $\exp \left(7.7234 \times 10^{-2} \times\left[\mathrm{O}_{3}\right] /\left(\mathrm{nmol} \mathrm{mol}^{-1}\right)-1.6363\right)$

at night. Then the $\mathrm{RO}_{2}$ mixing ratio was calculated as $70 \%$ of $\mathrm{HO}_{2}$ mixing ratios based on previous studies (Liu et al., 2012; Elshorbany et al., 2012; Mihelcic et al., 2003). As the NO mixing ratio was not observed in our study, we estimated NO mixing ratios following the empirical formulas between $\mathrm{NO}_{X}$ and $\mathrm{CO}$ mixing ratios derived from observations in winter Beijing (Lin et al., $2011)$; i.e., $[\mathrm{NO}] /\left(\mathrm{nmol} \mathrm{mol}^{-1}\right)=\left([\mathrm{CO}] /\left(\mathrm{nmol} \mathrm{mol}^{-1}\right)-\right.$ 196) $/ 27.3-\left[\mathrm{NO}_{2}\right] /\left(\mathrm{nmol} \mathrm{mol}^{-1}\right)$ during daytime and $[\mathrm{NO}] /\left(\mathrm{nmol} \mathrm{mol}^{-1}\right)=\left([\mathrm{CO}] /\left(\mathrm{nmol} \mathrm{mol}^{-1}\right)-105\right) / 30.9-$ $\left[\mathrm{NO}_{2}\right] /\left(\mathrm{nmol} \mathrm{mol}^{-1}\right)$ at night.

By using Eq. (2), the relative importance of nocturnal formation pathways $\left(f_{\mathrm{R} 8}+f_{\mathrm{R} 9}+f_{\mathrm{R} 10}\right)$ can be written as Eq. (4):

$f_{\mathrm{R} 8}+f_{\mathrm{R} 9}+f_{\mathrm{R} 10}=\frac{f_{\mathrm{R} 9}}{2}+\frac{\Delta^{17} \mathrm{O}\left(\mathrm{NO}_{3}^{-}\right)}{14 \% o}-1.8 \alpha$.
Equation (4) suggests that the relative importance of nocturnal pathways is solely a function of the assumption of $f_{\mathrm{R} 9}$ at given $\Delta^{17} \mathrm{O}\left(\mathrm{NO}_{3}^{-}\right)$and $\alpha$. Since $f_{\mathrm{R} 9}, f_{\mathrm{R} 8}+f_{\mathrm{R} 10}$, and $f_{\mathrm{R} 8}+f_{\mathrm{R} 9}+f_{\mathrm{R} 10}$ should be in the range of $0-1$ all the time, $f_{\mathrm{R} 9}$ is further limited to meet Eq. (5):

$f_{\mathrm{R} 9}\left\{\begin{array}{l}>0 \\ <\min \left(1, \frac{\Delta^{17} \mathrm{O}\left(\mathrm{NO}_{3}^{-}\right)}{7 \% o}-3.6 \alpha, 2+3.6 \alpha-\frac{\Delta^{17} \mathrm{O}\left(\mathrm{NO}_{3}^{-}\right)}{7 \%}\right) .\end{array}\right.$

We estimated the relative importance of nocturnal pathways $\left(f_{\mathrm{R} 8}+f_{\mathrm{R} 9}+f_{\mathrm{R} 10}\right)$ by using concentration-weighted $\Delta^{17} \mathrm{O}\left(\mathrm{NO}_{3}^{-}\right)$observations and production-rate-weighted $\alpha$ from PD of each haze event rather than each sample due to the lifetime of atmospheric nitrate is typically on the order of day (Liang et al., 1998), larger than our sampling collection interval.

\subsection{Simulation of surface $\mathrm{N}_{2} \mathrm{O}_{5}$ and $\mathrm{NO}_{3}$ radicals}

To see whether the relative importance of nocturnal pathways constrained by $\Delta^{17} \mathrm{O}\left(\mathrm{NO}_{3}^{-}\right)$can be reproduced by models, we use the standard Master Chemical Mechanism (MCM, version 3.3; http://mcm.leeds.ac.uk/, last access: 3 September 2018) to simulate the mixing ratios of surface $\mathrm{N}_{2} \mathrm{O}_{5}$ and $\mathrm{NO}_{3}$ radicals during our sampling period. The input for this modeling work includes (i) $1 \mathrm{~h}$ averaged mixing ratios of observed surface $\mathrm{CO}, \mathrm{NO}_{2}, \mathrm{SO}_{2}$, and $\mathrm{O}_{3}$ and estimated $\mathrm{NO}$ (see Sect. 2.3), (ii) observed $\mathrm{RH}$ and $T$, and (iii) the mixing ratios of organic compounds from the literature (Table S1) (Wang et al., 2001; Wu et al., 2016; Rao et al., 2016).

\section{Results and discussion}

\subsection{Overview of observations in Beijing haze}

Figure 3 describes general characteristics of haze events during our observations. The $12 \mathrm{~h}$ averaged $\mathrm{PM}_{2.5}$ concentrations, corresponding with filter samples, varied from 16 to $323 \mu \mathrm{g} \mathrm{m}^{-3}$ with a mean of $\left(141 \pm 88\right.$ (1 SD) $\mu \mathrm{g} \mathrm{m}^{-3}$. In comparison, the Grade II of NAAQS (National Ambient Air Quality Standard) in China is $75 \mu \mathrm{g} \mathrm{m}^{-3}$ for daily $\mathrm{PM}_{2.5}$. The $\mathrm{NO}_{3}^{-}$concentrations present similar trends with $\mathrm{PM}_{2.5}$ levels (Fig. 3a), ranging from 0.3 to $106.7 \mu \mathrm{g} \mathrm{m}^{-3}$ with a mean of $(6.1 \pm 5.3) \mu \mathrm{g} \mathrm{m}^{-3}$ on NPD $\left(\mathrm{PM}_{2.5}<75 \mu \mathrm{g} \mathrm{m}^{-3}\right)$ and $(48.4 \pm$ 24.7) $\mu \mathrm{g} \mathrm{m}^{-3}$ on $\mathrm{PD}\left(\mathrm{PM}_{2.5} \geq 75 \mu \mathrm{g} \mathrm{m}^{-3}\right)$. Correspondingly, the nitrogen oxidation ratio (NOR, which is equal to the $\mathrm{NO}_{3}^{-}$molar concentration divided by the sum of $\mathrm{NO}_{3}^{-}$and $\mathrm{NO}_{2}$ molar concentration), a proxy for secondary transformation of nitrate (Sun et al., 2006), increased from a mean of $0.09 \pm 0.05$ on NPD to $0.31 \pm 0.10$ on PD (Fig. 3b). In the residential heating season (Case III-V in November 2014 January 2015, Fig. 3b), $\mathrm{Cl}^{-}$concentrations present similar trends to $\mathrm{NO}_{3}^{-}$levels, increasing from $(0.6 \pm 1.0) \mu \mathrm{g} \mathrm{m}^{-3}$ on 
Table 2. Reaction expressions for different $\mathrm{NO}_{2}$ production pathways.

\begin{tabular}{|c|c|c|c|c|}
\hline No. & Reaction & Rate expression & $\begin{array}{l}\text { Rate constant } \\
\left(\mathrm{cm}^{3} \text { molecule }{ }^{-1} \mathrm{~s}^{-1}\right)\end{array}$ & Reference \\
\hline R1 & $\mathrm{NO}+\mathrm{O}_{3} \rightarrow \mathrm{NO}_{2}+\mathrm{O}_{2}$ & $k_{\mathrm{R} 1}[\mathrm{NO}]\left[\mathrm{O}_{3}\right]$ & $k_{\mathrm{R} 1}=3.0 \times 10^{-12} \times e^{(-1500 / T)}$ & Burkholder et al. (2015) \\
\hline $\mathrm{R} 2 \mathrm{a}$ & $\mathrm{NO}+\mathrm{HO}_{2} \rightarrow \mathrm{NO}_{2}+\mathrm{OH}$ & $k_{2 \mathrm{Ra}}[\mathrm{NO}]\left[\mathrm{HO}_{2}\right]$ & $k_{2 \mathrm{Ra}}=3.3 \times 10^{-12} \times e^{(270 / T)}$ & Burkholder et al. (2015) \\
\hline $\mathrm{R} 2 \mathrm{~b}$ & $\mathrm{NO}+\mathrm{RO}_{2} \rightarrow \mathrm{NO}_{2}+\mathrm{RO}$ & $k_{2 \mathrm{Rb}}[\mathrm{NO}]\left[\mathrm{RO}_{2}\right]$ & $k_{2 \mathrm{Rb}}=k_{2 \mathrm{Ra}}$ & Burkholder et al. (2015); Kunasek et al. (2008) \\
\hline
\end{tabular}

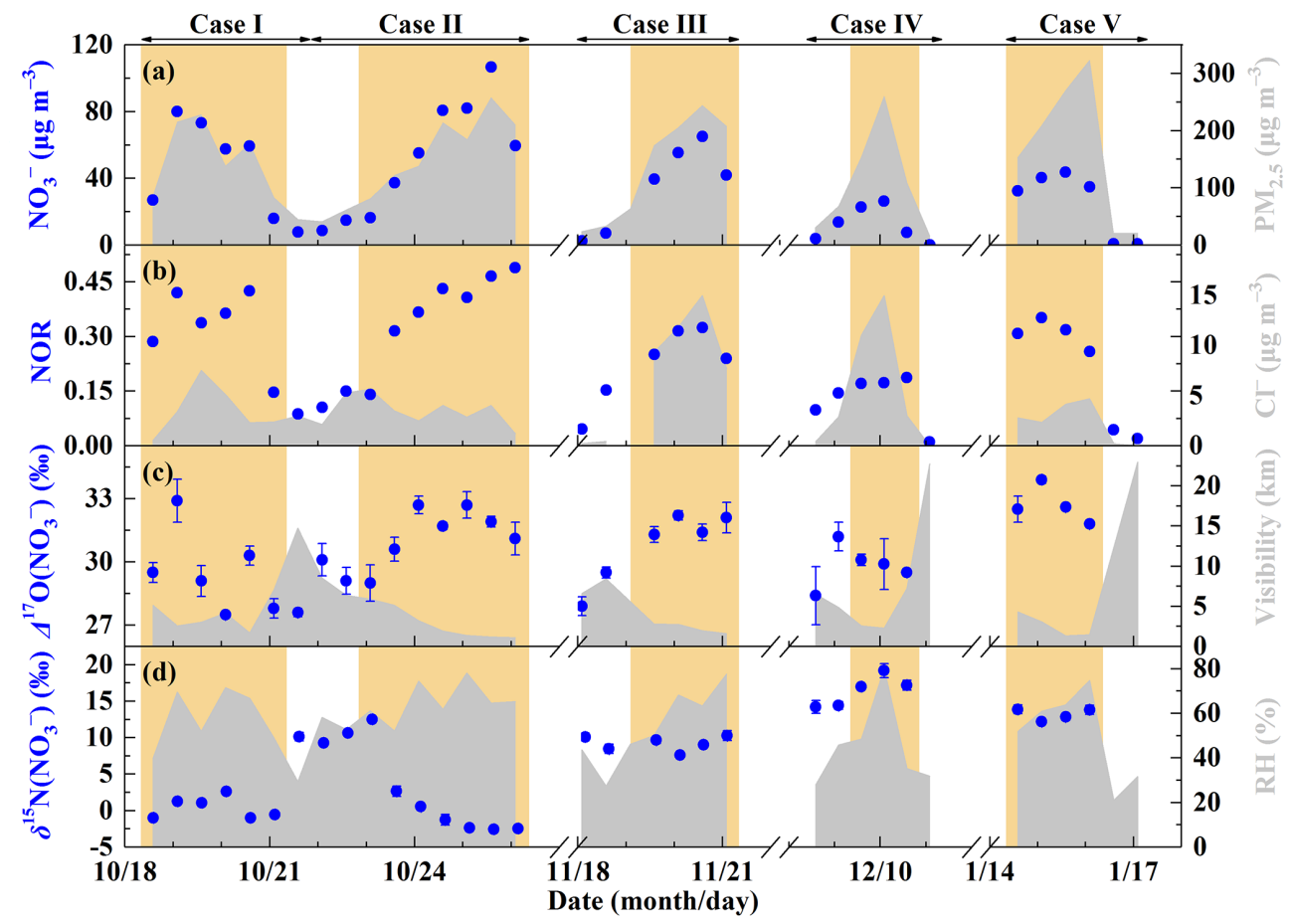

Figure 3. General characteristics of haze events in Beijing (October 2014-January 2015). (a) Time series of $\mathrm{PM}_{2.5}$ and $\mathrm{NO}_{3}^{-}$concentrations. (b) Time series of nitrogen oxidation ratio (NOR, which is equal to the $\mathrm{NO}_{3}^{-}$molar concentration divided by the sum of $\mathrm{NO}_{3}^{-}$and $\mathrm{NO}_{2}$ molar concentration) and $\mathrm{Cl}^{-}$concentrations. (c) Time series of $\Delta^{17} \mathrm{O}\left(\mathrm{NO}_{3}^{-}\right)$and visibility. (d) Time series of $\delta^{15} \mathrm{~N}\left(\mathrm{NO}_{3}^{-}\right)$and relative humidity $(\mathrm{RH})$. The error bars in (c, d) are $\pm 1 \sigma$ of replicate measurements $(n=3)$ of each sample. The khaki shaded area indicates polluted days $(\mathrm{PD}$, $\left.\mathrm{PM}_{2.5} \geq 75 \mu \mathrm{g} \mathrm{m}^{-3}\right)$.

NPD to (7.9 \pm 4.8$) \mu \mathrm{g} \mathrm{m}^{-3}$ on PD. However, during Case I-II in October 2014, $\mathrm{Cl}^{-}$concentrations were $(3.5 \pm 1.6) \mu \mathrm{g} \mathrm{m}^{-3}$ on NPD and (3.5 \pm 1.9$) \mu \mathrm{g} \mathrm{m}^{-3}$ on PD, showing no significant difference at the 0.01 level ( $t$ test). Throughout our observational period, the visibility decreased from $(11.4 \pm 6.7) \mathrm{km}$ on NPD to (3.1 \pm 1.8$) \mathrm{km}$ on PD (Fig. 3c), while RH increased from $(37 \pm 12) \%$ on NPD to $(62 \pm 12) \%$ on PD (Fig. 3d).

$\Delta^{17} \mathrm{O}\left(\mathrm{NO}_{3}^{-}\right)$ranged from $27.5 \%$ to $33.9 \%$ with a mean of $(29.1 \pm 1.3) \% o$ on NPD and $(31.0 \pm 1.7) \%$ on PD (Fig. 3c). Our observed $\Delta^{17} \mathrm{O}\left(\mathrm{NO}_{3}^{-}\right)$is in the range of aerosol $\Delta^{17} \mathrm{O}\left(\mathrm{NO}_{3}^{-}\right)$reported in the literature (Table 3) and wet deposition $\Delta^{17} \mathrm{O}\left(\mathrm{NO}_{3}^{-}\right)$observed in East Asia (Nelson et al., 2018; Tsunogai et al., 2010, 2016). All our observed $\Delta^{17} \mathrm{O}\left(\mathrm{NO}_{3}^{-}\right)$values, whether from the daytime sample (08:00-20:00) or the nighttime sample (20:00-08:00), are larger than $25 \%$, the maximum of $\Delta^{17} \mathrm{O}\left(\mathrm{NO}_{3}^{-}\right)$that can be produced via $\mathrm{NO}_{2}+\mathrm{OH}$ and $\mathrm{NO}_{2}+\mathrm{H}_{2} \mathrm{O}$ (Table 1) with the assumption of bulk $\Delta{ }^{17} \mathrm{O}\left(\mathrm{O}_{3}\right)=26 \%$ o (Ishino et al., 2017; Vicars and Savarino, 2014). This directly suggests that nocturnal formation pathways $\left(\mathrm{N}_{2} \mathrm{O}_{5}+\mathrm{H}_{2} \mathrm{O} / \mathrm{Cl}^{-}\right.$and $\mathrm{NO}_{3}+\mathrm{HC}$ ) must contribute to all the sampled nitrate. Given that the lifetime of atmospheric nitrate is typically larger than our sampling collection interval (Vicars et al., 2013), each of our samples is expected to reflect both daytime and nocturnal nitrate production. Not surprisingly, the $\Delta^{17} \mathrm{O}\left(\mathrm{NO}_{3}^{-}\right)$ mean of daytime and nighttime samples is $(30.3 \pm 1.5) \%$ and $(30.9 \pm 2.1) \%$, respectively, showing no significant difference at the 0.01 level $(t$ test).

$\delta^{15} \mathrm{~N}\left(\mathrm{NO}_{3}^{-}\right)$in our observation varied from $-2.5 \%$ to $19.2 \%$ with a mean of $(7.4 \pm 6.8) \%$, which is in the range of $\delta^{15} \mathrm{~N}\left(\mathrm{NO}_{3}^{-}\right)$observed from rainwater in Beijing, China (Zhang et al., 2008), and similar to $\delta^{15} \mathrm{~N}_{\left(\mathrm{NO}_{3}^{-}\right)}$values 
Table 3. Atmospheric $\Delta^{17} \mathrm{O}\left(\mathrm{NO}_{3}^{-}\right)$in aerosols obtained from the literature and this study.

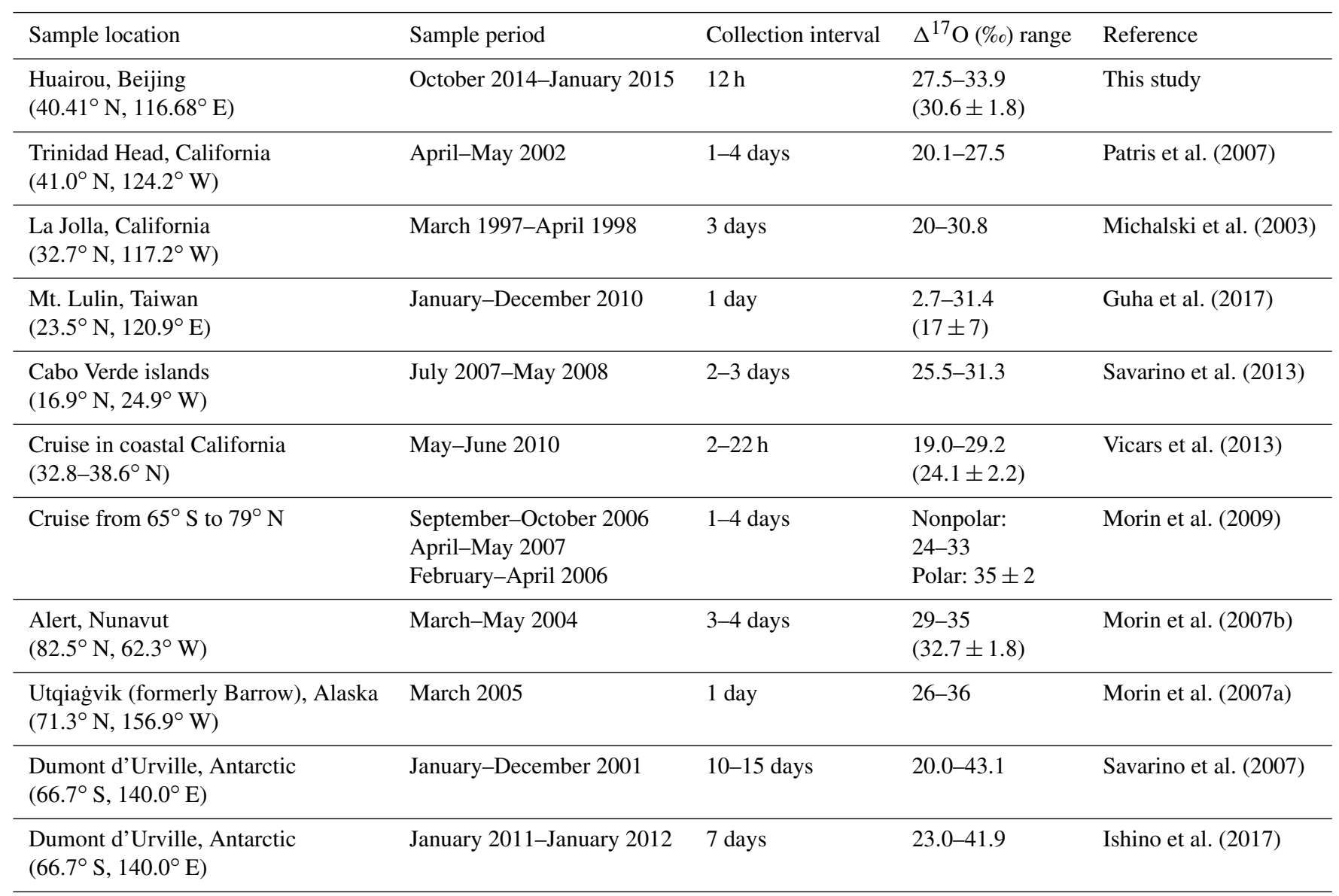

observed from aerosols in Germany (Freyer, 1991). Figure $3 \mathrm{~d}$ shows that $\delta^{15} \mathrm{~N}\left(\mathrm{NO}_{3}^{-}\right)$varies largely in October 2014. The mean $\delta^{15} \mathrm{~N}\left(\mathrm{NO}_{3}^{-}\right)$varied from $(0.4 \pm 1.5) \%$ in the period 08:00 on 18 October-08:00 on 21 October to $(10.7 \pm 1.4) \%$ in the period 08:00 on 21 October-08:00 on 23 October and then decreased to $(-0.9 \pm 2.1) \%$ in the period 08:00 on 23 October-08:00 on 26 October, which corresponds to $\mathrm{PM}_{2.5}$ concentrations being $155 \pm 63,57 \pm 19$, and $(188 \pm 51) \mu_{\mathrm{g} \mathrm{m}}^{-3}$ respectively. However, during the residential heating season, relatively high $\delta^{15} \mathrm{~N}\left(\mathrm{NO}_{3}^{-}\right)\left(7.6 \% 0^{-}\right.$ $19.2 \%$ ) levels were always observed, both on NPD and PD. This may be related to the high $\mathrm{NO}_{X}$ emission from coal combustion in north China (Wang et al., 2012; Lin, 2012; Zhang et al., 2007).

\subsection{Relationships between $\Delta^{17} \mathrm{O}\left(\mathrm{NO}_{3}^{-}\right)$and other data}

Figure 4 presents the relationships between $\Delta^{17} \mathrm{O}\left(\mathrm{NO}_{3}^{-}\right)$and $\mathrm{NO}_{3}^{-}$concentrations, $\mathrm{PM}_{2.5}$ concentrations, NOR, visibility, $\mathrm{RH}$, and $\delta^{15} \mathrm{~N}\left(\mathrm{NO}_{3}^{-}\right) . \Delta^{17} \mathrm{O}\left(\mathrm{NO}_{3}^{-}\right)$shows a positive correlation with $\mathrm{NO}_{3}^{-}$concentrations when $\mathrm{NO}_{3}^{-}<50 \mu \mathrm{g} \mathrm{m}^{-3}$ $(r=0.81, p<0.01)$. Similarly, $\Delta^{17} \mathrm{O}\left(\mathrm{NO}_{3}^{-}\right)$shows a positive correlation with $\mathrm{PM}_{2.5}$ concentration in Fig. $4 \mathrm{~b}$ and NOR in Fig. 4c when $\mathrm{NO}_{3}^{-}<50 \mu \mathrm{g} \mathrm{m}^{-3}(r=0.71$ and $r=0.80$, $p<0.01$, respectively). Figure $4 \mathrm{~d}$ shows that $\Delta^{17} \mathrm{O}\left(\mathrm{NO}_{3}^{-}\right)$ is negatively correlated with visibility in general $(r=-0.66$, $p<0.01)$. The significant decrease of visibility will largely reduce surface radiation and thereby $\mathrm{OH}$ mixing ratios (G. Zheng et al., 2015), which is unfavorable for nitrate production via the $\mathrm{NO}_{2}+\mathrm{OH}$ pathway. Since the $\mathrm{NO}_{2}+\mathrm{OH}$ pathway produces low $\Delta^{17} \mathrm{O}\left(\mathrm{NO}_{3}^{-}\right)$(Table 1$)$, the decreased importance of the $\mathrm{NO}_{2}+\mathrm{OH}$ pathway will conversely increase $\Delta^{17} \mathrm{O}\left(\mathrm{NO}_{3}^{-}\right)$. While the rise of $\mathrm{RH}$ accompanying the large increase of $\mathrm{PM}_{2.5}$ favors nitrate production via the heterogeneous uptake of gases, e.g., $\mathrm{N}_{2} \mathrm{O}_{5}$ (G. Zheng et al., 2015; B. Zheng et al., 2015), and the heterogeneous uptake of $\mathrm{N}_{2} \mathrm{O}_{5}$ produces relative high $\Delta^{17} \mathrm{O}\left(\mathrm{NO}_{3}^{-}\right)$(Table 1), the enhanced heterogeneous uptake of $\mathrm{N}_{2} \mathrm{O}_{5}$ will increase $\Delta^{17} \mathrm{O}\left(\mathrm{NO}_{3}^{-}\right)$too. Therefore, the decrease of the importance of $\mathrm{NO}_{2}+\mathrm{OH}$ and the increase of the importance of the heterogeneous uptake of $\mathrm{N}_{2} \mathrm{O}_{5}$ should be responsible for the positive correlation between $\Delta^{17} \mathrm{O}\left(\mathrm{NO}_{3}^{-}\right)$and $\mathrm{NO}_{3}^{-}$concentrations. In addition, for samples with $\mathrm{NO}_{3}^{-}>50 \mu \mathrm{g} \mathrm{m}^{-3}$, visibility was always low with narrow variations $(2.3 \pm$ $1.0 \mathrm{~km}$ ), and $\mathrm{RH}$ was always high with a narrow range 

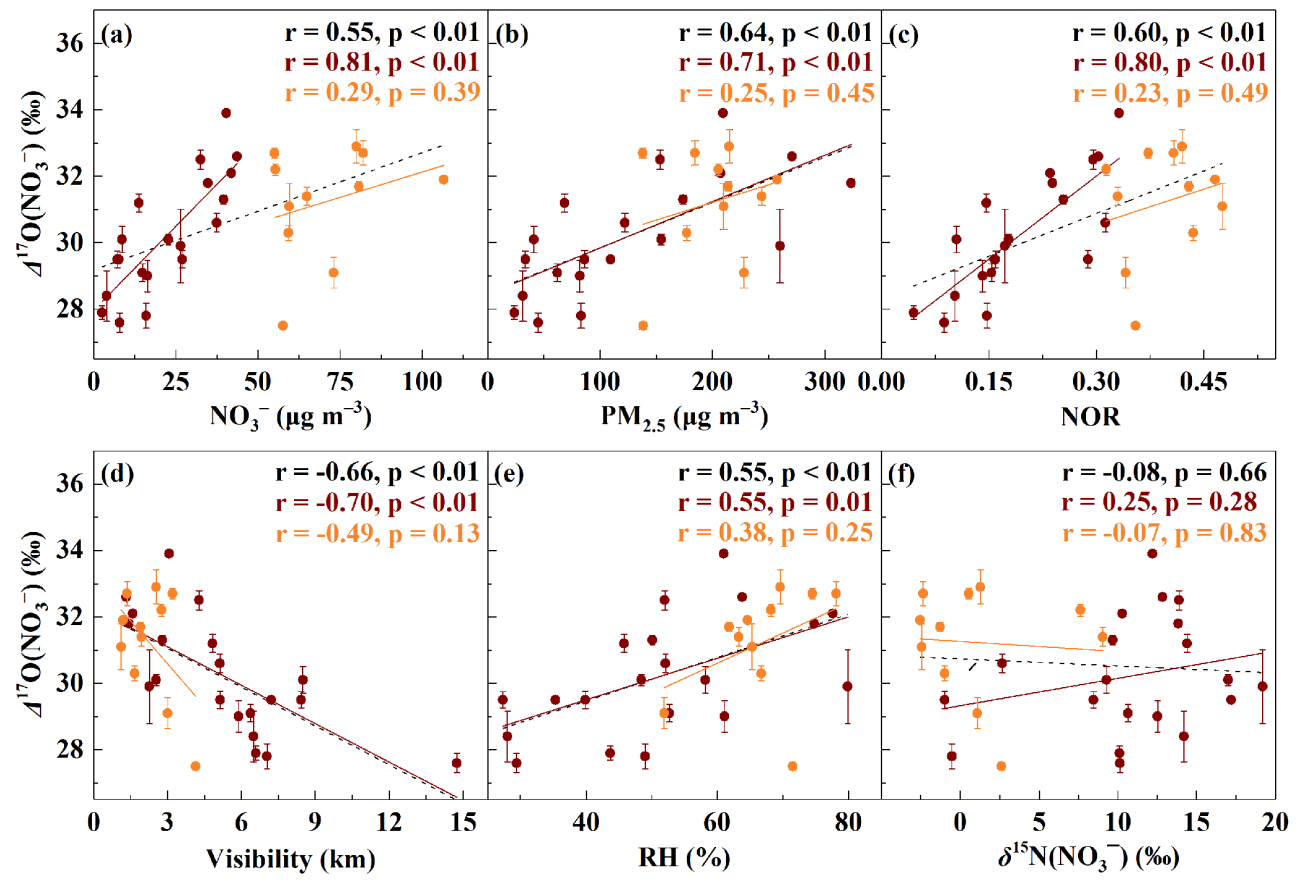

Figure 4. Relationships between $\Delta^{17} \mathrm{O}\left(\mathrm{NO}_{3}^{-}\right)$and other parameters. The relationship between $\Delta^{17} \mathrm{O}\left(\mathrm{NO}_{3}^{-}\right)$and $\mathrm{NO}_{3}^{-}$concentrations $($a), $\mathrm{PM}_{2.5}$ concentrations (b), nitrogen oxidation ratio (NOR, c), visibility (d), relative humidity $(\mathrm{RH}, \mathbf{e})$, and $\delta^{15} \mathrm{~N}\left(\mathrm{NO}_{3}^{-}\right)(\mathbf{f})$. The dark red dots are samples with $\mathrm{NO}_{3}^{-}<50 \mu \mathrm{g} \mathrm{m}^{-3}$ and the orange dots are samples with $\mathrm{NO}_{3}^{-}>50 \mu \mathrm{g} \mathrm{m}^{-3}$. The black dashed lines are linear least-squares fitting lines for all samples, the dark red solid lines are linear least-squares fitting lines for samples with $\mathrm{NO}_{3}^{-}<50 \mu \mathrm{g} \mathrm{m}^{-3}$, and the orange solid lines are linear least-squares fitting lines for samples with $\mathrm{NO}_{3}^{-}>50 \mu \mathrm{g} \mathrm{m}^{-3}$. The error bars are $\pm 1 \sigma$ of replicate measurements of each sample.

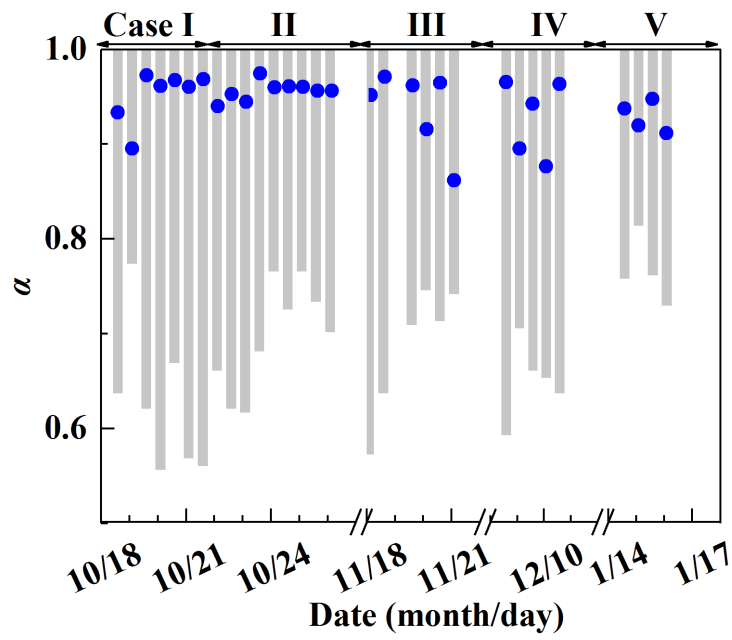

Figure 5. Estimate of the proportion of $\mathrm{O}_{3}$ oxidation in $\mathrm{NO}_{X}$ cycling, $\alpha$. The gray column represents the possible $\alpha$ range determined by $\Delta^{17} \mathrm{O}\left(\mathrm{NO}_{3}^{-}\right)$. The blue dot represents a specific $\alpha$ value calculated by Eq. (3).

$(67 \pm 7 \%)$, which may be the reason for the relatively high $\Delta^{17} \mathrm{O}\left(\mathrm{NO}_{3}^{-}\right)$being observed $(31.2 \pm 1.7 \%$ o). Figure $4 \mathrm{f}$ shows that $\Delta^{17} \mathrm{O}\left(\mathrm{NO}_{3}^{-}\right)$is not correlated with $\delta^{15} \mathrm{~N}\left(\mathrm{NO}_{3}^{-}\right)$.

\subsection{Estimate of nocturnal formation pathways}

Before estimating the relative importance of different nitrate formation pathways, we estimate the proportion of $\mathrm{O}_{3}$ oxidation in the $\mathrm{NO}_{2}$ production rate, $\alpha$. The possible $\alpha$ range can be calculated based on observed $\Delta^{17} \mathrm{O}\left(\mathrm{NO}_{3}^{-}\right)$. It can be obtained from Table 1 that $25 \alpha \% \circ<\Delta^{17} \mathrm{O}\left(\mathrm{NO}_{3}^{-}\right)<(25 \alpha+14) \%$, so the lower limit of possible $\alpha$ is $\left(\Delta^{17} \mathrm{O}\left(\mathrm{NO}_{3}^{-}\right)-14 \%\right.$ o $) / 25 \%$. And since $\Delta^{17} \mathrm{O}\left(\mathrm{NO}_{3}^{-}\right) \geq 27.5 \%$ in our observation, the higher limit of $\alpha$ is always 1 for all the samples. Figure 5 presents the possible range of calculated $\alpha$ based on $\Delta^{17} \mathrm{O}\left(\mathrm{NO}_{3}^{-}\right)$. The calculated lower limit of $\alpha$ ranged from 0.56 to 0.81 with a mean of $0.68 \pm 0.07$, which directly suggests that $\mathrm{O}_{3}$ oxidation played a dominated role in $\mathrm{NO}_{X}$ cycling during Beijing haze. To estimate the specific $\alpha$ value, chemical kinetics in Table 2 and Eq. (3) were used. Specific $\alpha$ is estimated to range from 0.86 to 0.97 with a mean of $(0.94 \pm 0.03)$, which is in the possible range of $\alpha$ value calculated directly based on $\Delta^{17} \mathrm{O}\left(\mathrm{NO}_{3}^{-}\right)$(Fig. 5) and close to the range of $0.85-1$ determined in other midlatitude areas (Michalski et al., 2003; Patris et al., 2007).

Figure 6a shows the estimated relative importance of nocturnal formation pathways $\left(\mathrm{N}_{2} \mathrm{O}_{5}+\mathrm{H}_{2} \mathrm{O} / \mathrm{Cl}^{-}\right.$and $\mathrm{NO}_{3}+$ $\mathrm{HC}$ ) during $\mathrm{PD}$ of each case on the basis of observed 
Table 4. The possible range of fractional contribution of different nitrate formation pathways during PD of each case estimated on the basis of observed $\Delta^{17} \mathrm{O}\left(\mathrm{NO}_{3}^{-}\right)^{\mathrm{a}}$.

\begin{tabular}{lrrrr}
\hline PD of case & $f_{\mathrm{R} 9}$ assumption $(\%)$ & $f_{\mathrm{R} 8}+f_{\mathrm{R} 9}+f_{\mathrm{R} 10}(\%)$ & $f_{\mathrm{R} 8}+f_{\mathrm{R} 10}(\%)$ & $f_{\mathrm{R} 6}+f_{\mathrm{R} 7}(\%)$ \\
\hline I & $0-97$ & $49-97$ & $0-49$ & $3-51$ \\
II & $0-83$ & $58-100$ & $17-58$ & $0-42$ \\
III & $0-80$ & $60-100$ & $20-60$ & $0-40$ \\
IV & $0-90$ & $45-90$ & $0-45$ & $10-55$ \\
V & $0-59$ & $70-100$ & $41-70$ & $0-30$ \\
\hline Average & $0-82$ & $56-97$ & $16-56$ & $3-44$ \\
\hline
\end{tabular}

${ }^{a} \mathrm{R} 6, \mathrm{R} 7, \mathrm{R} 8, \mathrm{R} 9$, and $\mathrm{R} 10$ are, respectively, $\mathrm{NO}_{2}+\mathrm{OH}, \mathrm{NO}_{2}+\mathrm{H}_{2} \mathrm{O}, \mathrm{NO}_{3}+\mathrm{HC}, \mathrm{N}_{2} \mathrm{O}_{5}+\mathrm{H}_{2} \mathrm{O}$, and $\mathrm{N}_{2} \mathrm{O}_{5}+\mathrm{Cl}^{-}$pathways.
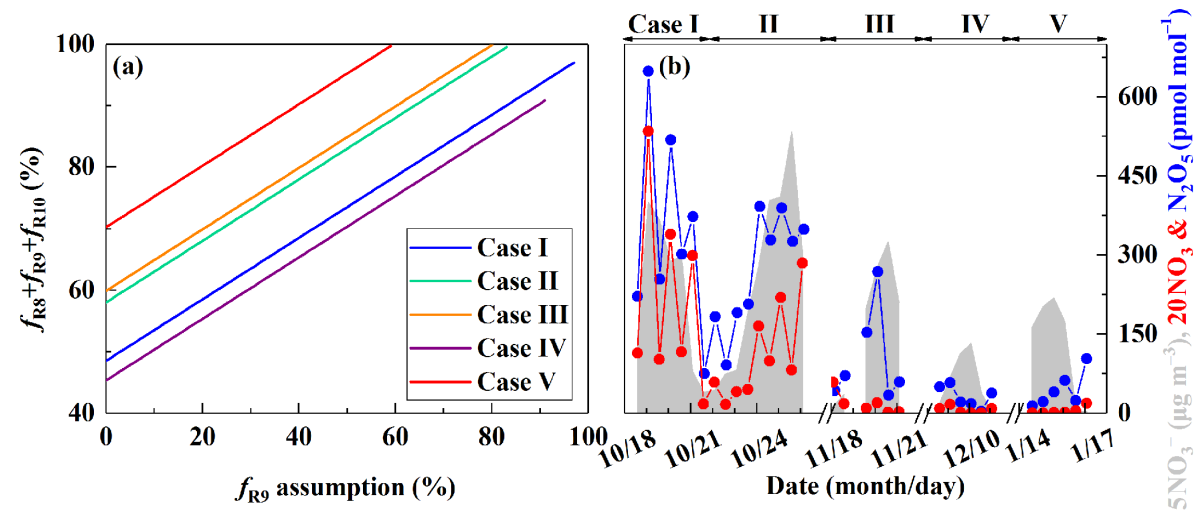

Figure 6. Estimate of the nocturnal formation pathways. The estimated relative importance of nocturnal formation pathways $\left(f_{\mathrm{R} 8}+f_{\mathrm{R} 9}+\right.$ $f_{\mathrm{R} 10}$ ) during $\mathrm{PD}$ of each case on the basis of observed $\Delta^{17} \mathrm{O}\left(\mathrm{NO}_{3}^{-}\right)$(see Sect. 2.3, a) and the simulated mixing ratios of $\mathrm{N}_{2} \mathrm{O}_{5}$ and $\mathrm{NO}_{3}$ radicals by $\mathrm{MCM}$ (b). $\mathrm{R} 8, \mathrm{R} 9$, and $\mathrm{R} 10$ in (a) represent $\mathrm{NO}_{3}+\mathrm{HC}, \mathrm{N}_{2} \mathrm{O}_{5}+\mathrm{H}_{2} \mathrm{O}$, and $\mathrm{N}_{2} \mathrm{O}_{5}+\mathrm{Cl}^{-}$pathways, respectively.

$\Delta^{17} \mathrm{O}\left(\mathrm{NO}_{3}^{-}\right)$. Possible fractional contributions of nocturnal formation pathways range from 49 to $97 \%, 58$ to $100 \%$, 60 to $100 \%, 45-90 \%$ and $70-100 \%$ on PD of Case I to $\mathrm{V}$, respectively, with a mean of 56-97\%. This directly implies that nocturnal chemistry dominates atmospheric nitrate production in Beijing haze. This finding is consistent with the suggested importance of the heterogeneous uptake of $\mathrm{N}_{2} \mathrm{O}_{5}$ during Beijing haze by previous studies (Su et al., 2017; Wang et al., 2017b). The other pathways $\left(\mathrm{NO}_{2}+\mathrm{OH}\right.$ and $\mathrm{NO}_{2}+\mathrm{H}_{2} \mathrm{O}$ ) account for the remaining fraction with a mean possible range of 3-44\%. Since $\mathrm{NO}_{2}+\mathrm{OH}$ and $\mathrm{NO}_{2}+\mathrm{H}_{2} \mathrm{O}$ produce the same $\Delta^{17} \mathrm{O}\left(\mathrm{NO}_{3}^{-}\right)$signature in our assumptions (Table 1), we cannot distinguish their fractional contributions purely from the observed $\Delta^{17} \mathrm{O}\left(\mathrm{NO}_{3}^{-}\right)$in the present study. However, the overall positive correlation between $\Delta^{17} \mathrm{O}\left(\mathrm{NO}_{3}^{-}\right)$and $\mathrm{RH}(r=0.55, p<0.01$; Fig. 4e) suggests that the heterogeneous uptake of $\mathrm{NO}_{2}$ should be less important than the heterogeneous uptake of $\mathrm{N}_{2} \mathrm{O}_{5}$; otherwise, a negative relationship between $\Delta^{17} \mathrm{O}\left(\mathrm{NO}_{3}^{-}\right)$and $\mathrm{RH}$ is expected. Our calculations also suggest that the sum of possible fractional contributions of $\mathrm{N}_{2} \mathrm{O}_{5}+\mathrm{Cl}^{-}$and $\mathrm{NO}_{3}+\mathrm{HC}$ is in the range of $0-49 \%, 17-58 \%, 20-60 \%, 0-45 \%$, and 41-70\% on PD of Case I to V, respectively, with a mean of
16-56\% (Table 4), which emphasizes that $\mathrm{N}_{2} \mathrm{O}_{5}+\mathrm{Cl}^{-}$and $\mathrm{NO}_{3}+\mathrm{HC}$ played a unignorable role in nitrate production during Beijing haze. Due to the fact that $\mathrm{N}_{2} \mathrm{O}_{5}+\mathrm{Cl}^{-}$and $\mathrm{NO}_{3}+\mathrm{HC}$ produce the same $\Delta^{17} \mathrm{O}\left(\mathrm{NO}_{3}^{-}\right)$in our assumptions (Table 1), we cannot distinguish their fractional contributions purely from the observed $\Delta^{17} \mathrm{O}\left(\mathrm{NO}_{3}^{-}\right)$in this study either. However, $\mathrm{NO}_{3}+\mathrm{HC}$ should be minor for nitrate production. For example, the 3-D modeling work of Alexander et al. (2009) suggests that the $\mathrm{NO}_{3}+\mathrm{HC}$ pathway only accounts for $4 \%$ of global tropospheric nitrate production annually on average, and Michalski et al. (2003) found that the $\mathrm{NO}_{3}+\mathrm{HC}$ pathway contributes $1-10 \%$ to nitrate production on the basis of an annual observation at La Jolla, California, with low values in winter. Therefore, in addition to $\mathrm{NO}_{3}+\mathrm{HC}, \mathrm{N}_{2} \mathrm{O}_{5}+\mathrm{Cl}^{-}$is likely to also contribute to nitrate production during haze in Beijing. In support of this, the concentrations of $\mathrm{Cl}^{-}$are as high as $(5.5 \pm 4.1) \mu \mathrm{g} \mathrm{m}^{-3}$ during $\mathrm{PD}$ of all the cases in our observation and the mixing ratios of $\mathrm{ClNO}_{2}$, an indicator of the $\mathrm{N}_{2} \mathrm{O}_{5}+\mathrm{Cl}^{-}$pathway, reached up to $2.9 \mathrm{nmol} \mathrm{mol}^{-1}$ during a summer observation in suburban Beijing (Wang et al., 2018b) and reached up to $5.0 \mathrm{nmol} \mathrm{mol}^{-1}$ in another modeling work in summer rural Beijing (Wang et al., 2017c). 
Figure $6 \mathrm{~b}$ presents the simulated mixing ratios of surface $\mathrm{N}_{2} \mathrm{O}_{5}$ and $\mathrm{NO}_{3}$ radicals during our observational period by using the box model MCM. The $12 \mathrm{~h}$ averaged mixing ratios of simulated $\mathrm{N}_{2} \mathrm{O}_{5}$ ranged from 3 to $649 \mathrm{pmol} \mathrm{mol}^{-1}$, while simulated $\mathrm{NO}_{3}$ radicals ranged from 0 to $27 \mathrm{pmol} \mathrm{mol}^{-1}$. In comparison, previous observations in Beijing suggest that $5 \mathrm{~s}$ averaged $\mathrm{N}_{2} \mathrm{O}_{5}$ can be as high as $1.3 \mathrm{nmol} \mathrm{mol}^{-1}$ and $30 \mathrm{~min}$ averaged $\mathrm{NO}_{3}$ radicals can be as high as $38 \mathrm{pmol} \mathrm{mol}^{-1}$, with large day-to-day variability (Wang et al., 2015, 2017b). During Case I and II in October, simulated $\mathrm{N}_{2} \mathrm{O}_{5}$ and $\mathrm{NO}_{3}$ radicals present similar trends with the observed $\mathrm{NO}_{3}^{-}$ and remain relatively high during PD $(346 \pm 128$ and $9 \pm$ $7 \mathrm{pmol} \mathrm{mol}^{-1}$, respectively, Fig. 6b), which supports the dominant role of nocturnal formation pathways suggested by $\Delta^{17} \mathrm{O}\left(\mathrm{NO}_{3}^{-}\right)$. However, during Case III-V in the residential heating season, the simulated surface mixing ratios of $\mathrm{N}_{2} \mathrm{O}_{5}$ and $\mathrm{NO}_{3}$ radicals remain relatively low during PD ( $63 \pm 80$ and $<1 \mathrm{pmol} \mathrm{mol}^{-1}$, respectively, Fig. $6 \mathrm{~b}$ ), which seems to be inconsistent with $\Delta^{17} \mathrm{O}\left(\mathrm{NO}_{3}^{-}\right)$observations. We note that a recent study suggests that the heterogeneous uptake of $\mathrm{N}_{2} \mathrm{O}_{5}$ is negligible at the surface but larger at higher altitudes (e.g., $>150 \mathrm{~m}$ ) during winter haze in Beijing (Wang et al., 2018a). So during PD of Case III-V in our observational period, large nitrate production via heterogeneous uptake of $\mathrm{N}_{2} \mathrm{O}_{5}$ may occur aloft rather than at the surface, which leads to the dominant role of nocturnal formation pathways as suggested by $\Delta^{17} \mathrm{O}\left(\mathrm{NO}_{3}^{-}\right)$.

\section{Conclusions}

We report the first observation of isotopic composition $\left(\Delta^{17} \mathrm{O}\right.$ and $\left.\delta^{15} \mathrm{~N}\right)$ of atmospheric nitrate in Beijing haze. The observed $\Delta^{17} \mathrm{O}\left(\mathrm{NO}_{3}^{-}\right)$ranged from $27.5 \%$ o to $33.9 \%$ with a mean of $(30.6 \pm 1.8) \%$ o. $\delta^{15} \mathrm{~N}\left(\mathrm{NO}_{3}^{-}\right)$ranged largely from $-2.5 \%$ o to $19.2 \%$ with a mean of $(7.4 \pm 6.8) \%$. When $\mathrm{NO}_{3}^{-}$ is $<50 \mu \mathrm{g} \mathrm{m}^{-3}$, a positive correlation was observed between $\Delta^{17} \mathrm{O}\left(\mathrm{NO}_{3}^{-}\right)$and $\mathrm{NO}_{3}^{-}$concentration $(r=0.81, p<0.01)$. This is likely to result from the variation of relative importance of different nitrate formation pathways. Calculations with the constraint of $\Delta^{17} \mathrm{O}\left(\mathrm{NO}_{3}^{-}\right)$suggest that nocturnal pathways $\left(\mathrm{N}_{2} \mathrm{O}_{5}+\mathrm{H}_{2} \mathrm{O} / \mathrm{Cl}^{-}\right.$and $\left.\mathrm{NO}_{3}+\mathrm{HC}\right)$ dominated nitrate production during polluted days $\left(\mathrm{PM}_{2.5} \geq 75 \mu \mathrm{g} \mathrm{m}{ }^{-3}\right.$ ), with a mean possible contribution of $56-97 \% . \Delta^{17} \mathrm{O}\left(\mathrm{NO}_{3}^{-}\right)$ also indicates that $\mathrm{O}_{3}$ dominated $\mathrm{NO}$ oxidation during Beijing haze.

Data availability. All data needed to draw the conclusions are present in the main text and/or the Supplement. For additional data, please contact the corresponding author (zqxie@ustc.edu.cn).

Supplement. The supplement related to this article is available online at: https://doi.org/10.5194/acp-18-14465-2018-supplement.
Author contributions. ZX conceived this study. $\mathrm{PH}$ conducted isotope measurements. $\mathrm{PH}, \mathrm{XC}, \mathrm{SF}, \mathrm{HZ}$, and $\mathrm{HK}$ performed the field experiments and ion measurements. $\mathrm{PH}, \mathrm{ZX}$, and $\mathrm{XY}$ interpreted the data. CL contributed to the field observation support. PH wrote the manuscript with input from ZX. All authors were involved in the discussion and revision of the manuscript.

Competing interests. The authors declare that they have no conflict of interest.

Special issue statement. This article is part of the special issue "Multiphase chemistry of secondary aerosol formation under severe haze". It is not associated with a conference.

Acknowledgements. This work was supported by the National Key Project of MOST (2016YFC0203302), NSFC (91544013), the Key Project of CAS (KJZD-EW-TZ-G06-01), and the Atmospheric Pollution Control of the Prime Minister (DQGG0104). We gratefully thank staff of IsoLab at UW for their technical support, and Becky Alexander and Lei Geng for helpful discussions.

Edited by: Jian Wang

Reviewed by: Jochen Rudolph, Greg Michalski, and two anonymous referees

\section{References}

Alexander, B., Hastings, M. G., Allman, D. J., Dachs, J., Thornton, J. A., and Kunasek, S. A.: Quantifying atmospheric nitrate formation pathways based on a global model of the oxygen isotopic composition $\left(\Delta^{17} \mathrm{O}\right)$ of atmospheric nitrate, Atmos. Chem. Phys., 9, 5043-5056, https://doi.org/10.5194/acp-9-5043-2009, 2009.

Berhanu, T. A., Savarino, J., Bhattacharya, S. K., and Vicars, W. C.: ${ }^{17} \mathrm{O}$ excess transfer during the $\mathrm{NO}_{2}+\mathrm{O}_{3} \rightarrow \mathrm{NO}_{3}+\mathrm{O}_{2}$ reaction, J. Chem. Phys., 136, 044311, https://doi.org/10.1063/1.3666852, 2012.

Bertram, T. H. and Thornton, J. A.: Toward a general parameterization of $\mathrm{N}_{2} \mathrm{O}_{5}$ reactivity on aqueous particles: the competing effects of particle liquid water, nitrate and chloride, Atmos. Chem. Phys., 9, 8351-8363, https://doi.org/10.5194/acp-9-8351-2009, 2009.

Beyn, F., Matthias, V., and Dähnke, K.: Changes in atmospheric nitrate deposition in Germany - An isotopic perspective, Environ. Pollut., 194, 1-10, 2014.

Brenninkmeijer, C. A., Janssen, C., Kaiser, J., Röckmann, T., Rhee, T. S., and Assonov, S. S.: Isotope effects in the chemistry of atmospheric trace compounds, Chem. Rev., 103, 5125-5162, 2003.

Brook, R. D., Rajagopalan, S., Pope, C. A., Brook, J. R., Bhatnagar, A., Diez-Roux, A. V., Holguin, F., Hong, Y., Luepker, R. V., and Mittleman, M. A.: Particulate matter air pollution and cardiovascular disease an update to the scientific statement from the American Heart Association, Circulation, 121, 2331-2378, 2010 . 
Brown, S. S. and Stutz, J.: Nighttime radical observations and chemistry, Chem. Soc. Rev., 41, 6405-6447, 2012.

Burkholder, J. B., Sander, S. P., Abbatt, J. P. D., Barker, J. R., Huie, R. E., Kolb, C. E., Kurylo, M. J., Orkin, V. L., Wilmouth, D. M., and Wine, P. H.: Chemical Kinetics and Photochemical Data for Use in Atmospheric Studies: Evaluation Number 18, Pasadena, CA, Jet Propulsion Laboratory, National Aeronautics and Space Administration, 2015.

Chen, Q., Geng, L., Schmidt, J. A., Xie, Z., Kang, H., Dachs, J., Cole-Dai, J., Schauer, A. J., Camp, M. G., and Alexander, B.: Isotopic constraints on the role of hypohalous acids in sulfate aerosol formation in the remote marine boundary layer, Atmos. Chem. Phys., 16, 11433-11450, https://doi.org/10.5194/acp-1611433-2016, 2016.

Chen, Z., Zhang, J., Zhang, T., Liu, W., and Liu, J.: Haze observations by simultaneous lidar and WPS in Beijing before and during APEC, 2014, Sci. China Chem., 58, 1385-1392, 2015.

Cheng, Z., Jiang, J., Fajardo, O., Wang, S., and Hao, J.: Characteristics and health impacts of particulate matter pollution in China (2001-2011), Atmos. Environ., 65, 186-194, 2013.

Cheung, J. L., Li, Y., Boniface, J., Shi, Q., Davidovits, P., Worsnop, D. R., Jayne, J. T., and Kolb, C. E.: Heterogeneous interactions of $\mathrm{NO}_{2}$ with aqueous surfaces, J. Phys. Chem. A, 104, 2655-2662, 2000.

Elliott, E. M., Kendall, C., Boyer, E. W., Burns, D. A., Lear, G. G., Golden, H. E., Harlin, K., Bytnerowicz, A., Butler, T. J., and Glatz, R.: Dual nitrate isotopes in dry deposition: Utility for partitioning $\mathrm{NO}_{x}$ source contributions to landscape nitrogen deposition, J. Geophys. Res.-Biogeo., 114, G04020, https://doi.org/10.1029/2008JG000889, 2009.

Elshorbany, Y. F., Kleffmann, J., Hofzumahaus, A., Kurtenbach, R., Wiesen, P., Brauers, T., Bohn, B., Dorn, H. P., Fuchs, H., and Holland, F.: $\mathrm{HO}_{x}$ budgets during HOxComp: A case study of $\mathrm{HO}_{x}$ chemistry under NOx-limited conditions, J. Geophys. Res., 117, D03307, https://doi.org/10.1029/2011JD017008, 2012.

Fang, Y. T., Koba, K., Wang, X. M., Wen, D. Z., Li, J., Takebayashi, Y., Liu, X. Y., and Yoh, M.: Anthropogenic imprints on nitrogen and oxygen isotopic composition of precipitation nitrate in a nitrogen-polluted city in southern China, Atmos. Chem. Phys., 11, 1313-1325, https://doi.org/10.5194/acp-111313-2011, 2011.

Felix, J. D., Elliott, E. M., and Shaw, S. L.: Nitrogen isotopic composition of coal-fired power plant $\mathrm{NO}_{x}$ : influence of emission controls and implications for global emission inventories, Environ. Sci. Technol., 46, 3528-3535, 2012.

Freyer, H. D.: Seasonal variation of ${ }^{15} \mathrm{~N} /{ }^{14} \mathrm{~N}$ ratios in atmospheric nitrate species, Tellus B, 43, 30-44, 1991.

Freyer, H. D., Kley, D., Volz-Thomas, A., and Kobel, K.: On the interaction of isotopic exchange processes with photochemical reactions in atmospheric oxides of nitrogen, J. Geophys. Res.Atmos., 98, 14791-14796, 1993.

Geng, L., Alexander, B., Cole-Dai, J., Steig, E. J., Savarino, J., Sofen, E. D., and Schauer, A. J.: Nitrogen isotopes in ice core nitrate linked to anthropogenic atmospheric acidity change, P. Natl. Acad. Sci. USA, 111, 5808-5812, 2014.

Goodman, A. L., Underwood, G. M., and Grassian, V. H.: Heterogeneous reaction of $\mathrm{NO}_{2}$ : Characterization of gas-phase and adsorbed products from the reaction,
$2 \mathrm{NO}_{2}(\mathrm{~g})+\mathrm{H}_{2} \mathrm{O}(\mathrm{a}) \rightarrow \mathrm{HONO}(\mathrm{g})+\mathrm{HNO}_{3}$ (a) on hydrated silica particles, J. Phys. Chem. A, 103, 7217-7223, 1999.

Guha, T., Lin, C. T., Bhattacharya, S. K., Mahajan, A. S., Ou-Yang, C.-F., Lan, Y.-P., Hsu, S. C., and Liang, M.-C.: Isotopic ratios of nitrate in aerosol samples from Mt. Lulin, a high-altitude station in Central Taiwan, Atmos. Environ., 154, 53-69, 2017.

Hastings, M. G., Casciotti, K. L., and Elliott, E. M.: Stable isotopes as tracers of anthropogenic nitrogen sources, deposition, and impacts, Elements, 9, 339-344, 2013.

He, P., Alexander, B., Geng, L., Chi, X., Fan, S., Zhan, H., Kang, H., Zheng, G., Cheng, Y., Su, H., Liu, C., and Xie, Z.: Isotopic constraints on heterogeneous sulfate production in Beijing haze, Atmos. Chem. Phys., 18, 5515-5528, https://doi.org/10.5194/acp18-5515-2018, 2018.

Hoering, T.: The isotopic composition of the ammonia and the nitrate ion in rain, Geochim. Cosmochim. Acta, 12, 97-102, 1957.

Ishino, S., Hattori, S., Savarino, J., Jourdain, B., Preunkert, S., Legrand, M., Caillon, N., Barbero, A., Kuribayashi, K., and Yoshida, N.: Seasonal variations of triple oxygen isotopic compositions of atmospheric sulfate, nitrate, and ozone at Dumont d'Urville, coastal Antarctica, Atmos. Chem. Phys., 17, 37133727, https://doi.org/10.5194/acp-17-3713-2017, 2017.

Kaiser, J., Hastings, M. G., Houlton, B. Z., Röckmann, T., and Sigman, D. M.: Triple oxygen isotope analysis of nitrate using the denitrifier method and thermal decomposition of $\mathrm{N}_{2} \mathrm{O}$, Anal. Chem., 79, 599-607, 2007.

Kanaya, Y., Cao, R., Akimoto, H., Fukuda, M., Komazaki, Y., Yokouchi, Y., Koike, M., Tanimoto, H., Takegawa, N., and Kondo, Y.: Urban photochemistry in central Tokyo: 1. Observed and modeled $\mathrm{OH}$ and $\mathrm{HO}_{2}$ radical concentrations during the winter and summer of 2004, J. Geophys. Res., 112, D21312, https://doi.org/10.1029/2007JD008670, 2007.

Kunasek, S. A., Alexander, B., Steig, E. J., Hastings, M. G., Gleason, D. J., and Jarvis, J. C.: Measurements and modeling of $\Delta^{17} \mathrm{O}$ of nitrate in snowpits from Summit, Greenland, J. Geophys. Res., 113, D24302, https://doi.org/10.1029/2008JD010103, 2008.

Li, H. J., Zhu, T., Zhao, D. F., Zhang, Z. F., and Chen, Z. M.: Kinetics and mechanisms of heterogeneous reaction of $\mathrm{NO}_{2}$ on $\mathrm{CaCO}_{3}$ surfaces under dry and wet conditions, Atmos. Chem. Phys., 10, 463-474, https://doi.org/10.5194/acp-10-463-2010, 2010.

Li, Z., Hu, R., Xie, P., Wang, H., Lu, K., and Wang, D.: Intercomparison of in situ CRDS and CEAS for measurements of atmospheric $\mathrm{N}_{2} \mathrm{O}_{5}$ in Beijing, China, Sci. Total Environ., 613, 131139, 2018.

Liang, J., Horowitz, L. W., Jacob, D. J., Wang, Y., Fiore, A. M., Logan, J. A., Gardner, G. M., and Munger, J. W.: Seasonal budgets of reactive nitrogen species and ozone over the United States, and export fluxes to the global atmosphere, J. Geophys. Res.-Atmos., 103, 13435-13450, 1998.

Lin, J.-T.: Satellite constraint for emissions of nitrogen oxides from anthropogenic, lightning and soil sources over East China on a high-resolution grid, Atmos. Chem. Phys., 12, 2881-2898, https://doi.org/10.5194/acp-12-2881-2012, 2012.

Lin, W., Xu, X., Ge, B., and Liu, X.: Gaseous pollutants in Beijing urban area during the heating period 2007-2008: variability, sources, meteorological, and chemical impacts, Atmos. 
Chem. Phys., 11, 8157-8170, https://doi.org/10.5194/acp-118157-2011, 2011.

Liu, Z., Wang, Y., Gu, D., Zhao, C., Huey, L. G., Stickel, R., Liao, J., Shao, M., Zhu, T., Zeng, L., Amoroso, A., Costabile, F., Chang, C.-C., and Liu, S.-C.: Summertime photochemistry during CAREBeijing-2007: $\mathrm{RO}_{x}$ budgets and $\mathrm{O}_{3}$ formation, Atmos. Chem. Phys., 12, 7737-7752, https://doi.org/10.5194/acp12-7737-2012, 2012.

Michalski, G., Scott, Z., Kabiling, M., and Thiemens, M. H.: First measurements and modeling of $\Delta^{17} \mathrm{O}$ in atmospheric nitrate, Geophys. Res. Lett., 30, 1870, https://doi.org/10.1029/2003GL017015, 2003.

Mihelcic, D., Holland, F., Hofzumahaus, A., Hoppe, L., Konrad, S., Müsgen, P., Pätz, H. W., Schäfer, H. J., Schmitz, T., and VolzThomas, A.: Peroxy radicals during BERLIOZ at Pabstthum: Measurements, radical budgets and ozone production, J. Geophys. Res., 108, 8254, https://doi.org/10.1029/2001JD001014, 2003.

Morin, S., Savarino, J., Bekki, S., Cavender, A., Shepson, P. B., and Bottenheim, J. W.: Major influence of $\mathrm{BrO}$ on the NOx and nitrate budgets in the Arctic spring, inferred from $\Delta^{17} \mathrm{O}\left(\mathrm{NO}_{3}^{-}\right)$ measurements during ozone depletion events, Environ. Chem., 4, 238-241, https://doi.org/10.1071/EN07003, 2007a.

Morin, S., Savarino, J., Bekki, S., Gong, S., and Bottenheim, J. W.: Signature of Arctic surface ozone depletion events in the isotope anomaly $\left(\Delta^{17} \mathrm{O}\right)$ of atmospheric nitrate, Atmos. Chem. Phys., 7, 1451-1469, https://doi.org/10.5194/acp-7-1451-2007, $2007 \mathrm{~b}$.

Morin, S., Savarino, J., Frey, M. M., Yan, N., Bekki, S., Bottenheim, J. W., and Martins, J. M.: Tracing the origin and fate of $\mathrm{NO}_{x}$ in the Arctic atmosphere using stable isotopes in nitrate, Science, 322, 730-732, 2008.

Morin, S., Savarino, J., Frey, M. M., Domine, F., Jacobi, H. W., Kaleschke, L., and Martins, J. M.: Comprehensive isotopic composition of atmospheric nitrate in the Atlantic Ocean boundary layer from $65 \mathrm{~S}$ to $79 \mathrm{~N}$, J. Geophys. Res.-Atmos., 114, D05303, https://doi.org/10.1029/2008JD010696, 2009.

Morin, S., Sander, R., and Savarino, J.: Simulation of the diurnal variations of the oxygen isotope anomaly $\left(\Delta^{17} \mathrm{O}\right)$ of reactive atmospheric species, Atmos. Chem. Phys., 11, 3653-3671, https://doi.org/10.5194/acp-11-3653-2011, 2011.

Nelson, D. M., Tsunogai, U., Ding, D., Ohyama, T., Komatsu, D. D., Nakagawa, F., Noguchi, I., and Yamaguchi, T.: Triple oxygen isotopes indicate urbanization affects sources of nitrate in wet and dry atmospheric deposition, Atmos. Chem. Phys., 18, 63816392, https://doi.org/10.5194/acp-18-6381-2018, 2018.

Pathak, R. K., Wu, W. S., and Wang, T.: Summertime $\mathrm{PM}_{2.5}$ ionic species in four major cities of China: nitrate formation in an ammonia-deficient atmosphere, Atmos. Chem. Phys., 9, 17111722, https://doi.org/10.5194/acp-9-1711-2009, 2009.

Pathak, R. K., Wang, T., and Wu, W. S.: Nighttime enhancement of $\mathrm{PM}_{2.5}$ nitrate in ammonia-poor atmospheric conditions in Beijing and Shanghai: plausible contributions of heterogeneous hydrolysis of $\mathrm{N}_{2} \mathrm{O}_{5}$ and $\mathrm{HNO}_{3}$ partitioning, Atmos. Environ., 45, 1183-1191, 2011.

Patris, N., Cliff, S. S., Quinn, P. K., Kasem, M., and Thiemens, M. H.: Isotopic analysis of aerosol sulfate and nitrate during ITCT-2k2: Determination of different formation pathways as a function of particle size, J. Geophys. Res.-Atmos., 112, D23301, https://doi.org/10.1029/2005JD006214, 2007.
Rao, Z., Chen, Z., Liang, H., Huang, L., and Huang, D.: Carbonyl compounds over urban Beijing: Concentrations on haze and nonhaze days and effects on radical chemistry, Atmos. Environ., 124, 207-216, 2016.

Savarino, J. and Thiemens, M. H.: Analytical procedure to determine both $\delta^{18} \mathrm{O}$ and $\delta^{17} \mathrm{O}$ of $\mathrm{H}_{2} \mathrm{O}_{2}$ in natural water and first measurements, Atmos. Environ., 33, 3683-3690, 1999.

Savarino, J., Kaiser, J., Morin, S., Sigman, D. M., and Thiemens, M. H.: Nitrogen and oxygen isotopic constraints on the origin of atmospheric nitrate in coastal Antarctica, Atmos. Chem. Phys. 7, 1925-1945, https://doi.org/10.5194/acp-7-1925-2007, 2007.

Savarino, J., Bhattacharya, S. K., Morin, S., Baroni, M., and Doussin, J.-F.: The $\mathrm{NO}+\mathrm{O}_{3}$ reaction: A triple oxygen isotope perspective on the reaction dynamics and atmospheric implications for the transfer of the ozone isotope anomaly, J. Chem. Phys., 128, 194303, https://doi.org/10.1063/1.2917581, 2008.

Savarino, J., Morin, S., Erbland, J., Grannec, F., Patey, M. D., Vicars, W., Alexander, B., and Achterberg, E. P.: Isotopic composition of atmospheric nitrate in a tropical marine boundary layer, P. Natl. Acad. Sci. USA, 110, 17668-17673, 2013.

Sofen, E. D., Alexander, B., Steig, E. J., Thiemens, M. H., Kunasek, S. A., Amos, H. M., Schauer, A. J., Hastings, M. G., Bautista, J., Jackson, T. L., Vogel, L. E., McConnell, J. R., Pasteris, D. R., and Saltzman, E. S.: WAIS Divide ice core suggests sustained changes in the atmospheric formation pathways of sulfate and nitrate since the 19th century in the extratropical Southern Hemisphere, Atmos. Chem. Phys., 14, 5749-5769, https://doi.org/10.5194/acp-14-5749-2014, 2014.

Su, X., Tie, X., Li, G., Cao, J., Huang, R., Feng, T., Long, X., and $\mathrm{Xu}, \mathrm{R}$. : Effect of hydrolysis of $\mathrm{N}_{2} \mathrm{O}_{5}$ on nitrate and ammonium formation in Beijing China: WRF-Chem model simulation, Sci. Total Environ., 579, 221-229, 2017.

Sun, Y., Zhuang, G., Tang, A., Wang, Y., and An, Z.: Chemical characteristics of $\mathrm{PM}_{2.5}$ and $\mathrm{PM}_{10}$ in haze-fog episodes in Beijing, Environ. Sci. Technol., 40, 3148-3155, 2006.

Tong, S., Hou, S., Zhang, Y., Chu, B., Liu, Y., He, H., Zhao, P., and $\mathrm{Ge}$, M.: Comparisons of measured nitrous acid (HONO) concentrations in a pollution period at urban and suburban Beijing, in autumn of 2014, Sci. China Chem., 58, 1393-1402, 2015.

Tsunogai, U., Komatsu, D. D., Daita, S., Kazemi, G. A., Nakagawa, F., Noguchi, I., and Zhang, J.: Tracing the fate of atmospheric nitrate deposited onto a forest ecosystem in Eastern Asia using $\Delta^{17} \mathrm{O}$, Atmos. Chem. Phys., 10, 1809-1820, https://doi.org/10.5194/acp-10-1809-2010, 2010.

Tsunogai, U., Miyauchi, T., Ohyama, T., Komatsu, D. D., Nakagawa, F., Obata, Y., Sato, K., and Ohizumi, T.: Accurate and precise quantification of atmospheric nitrate in streams draining land of various uses by using triple oxygen isotopes as tracers, Biogeosciences, 13, 3441-3459, https://doi.org/10.5194/bg-133441-2016, 2016.

Vicars, W. C., Morin, S., Savarino, J., Wagner, N. L., Erbland, J., Vince, E., Martins, J. M. F., Lerner, B. M., Quinn, P. K., and Coffman, D. J.: Spatial and diurnal variability in reactive nitrogen oxide chemistry as reflected in the isotopic composition of atmospheric nitrate: Results from the CalNex 2010 field study, J. Geophys. Res.-Atmos., 118, 10567-10588, https://doi.org/10.1002/jgrd.50680, 2013.

Vicars, W. C. and Savarino, J.: Quantitative constraints on the ${ }^{17} \mathrm{O}$ excess $\left(\Delta^{17} \mathrm{O}\right)$ signature of surface ozone: Ambient measure- 
ments from $50^{\circ} \mathrm{N}$ to $50^{\circ} \mathrm{S}$ using the nitrite-coated filter technique, Geochim. Cosmochim. Acta, 135, 270-287, 2014.

Walters, W. W., Simonini, D. S., and Michalski, G.: Nitrogen isotope exchange between $\mathrm{NO}$ and $\mathrm{NO}_{2}$ and its implications for $\delta^{15} \mathrm{~N}$ variations in tropospheric NOx and atmospheric nitrate, Geophys. Res. Lett., 43, 440-448, 2016.

Wang, D., Hu, R., Xie, P., Liu, J., Liu, W., Qin, M., Ling, L., Zeng, Y., Chen, H., Xing, X., Zhu, G., Wu, J., Duan, J., Lu, X., and Shen, L.: Diode laser cavity ring-down spectroscopy for in situ measurement of $\mathrm{NO}_{3}$ radical in ambient air, J. Quant. Spectrosc. Radiat. Transf., 166, 23-29, 2015.

Wang, H., Chen, J., and Lu, K.: Development of a portable cavityenhanced absorption spectrometer for the measurement of ambient $\mathrm{NO}_{3}$ and $\mathrm{N}_{2} \mathrm{O}_{5}$ : experimental setup, lab characterizations, and field applications in a polluted urban environment, Atmos. Meas. Tech., 10, 1465-1479, https://doi.org/10.5194/amt10-1465-2017, 2017a.

Wang, H., Lu, K., Chen, X., Zhu, Q., Chen, Q., Guo, S., Jiang, M., $\mathrm{Li}$, X., Shang, D., and Tan, Z.: High $\mathrm{N}_{2} \mathrm{O}_{5}$ concentrations observed in urban Beijing: Implications of a large nitrate formation pathway, Environ. Sci. Technol. Lett., 4, 416-420, $2017 \mathrm{~b}$.

Wang, H., Lu, K., Tan, Z., Sun, K., Li, X., Hu, M., Shao, M., Zeng, L., Zhu, T., and Zhang, Y.: Model simulation of $\mathrm{NO}_{3}, \mathrm{~N}_{2} \mathrm{O}_{5}$ and $\mathrm{ClNO}_{2}$ at a rural site in Beijing during CAREBeijing-2006, Atmos. Res., 196, 97-107, 2017c.

Wang, H., Lu, K., Chen, X., Zhu, Q., Wu, Z., Wu, Y., and Sun, K.: Fast particulate nitrate formation via $\mathrm{N}_{2} \mathrm{O}_{5}$ uptake aloft in winter in Beijing, Atmos. Chem. Phys., 18, 10483-10495, https://doi.org/10.5194/acp-18-10483-2018, 2018 a.

Wang, H., Lu, K., Guo, S., Wu, Z., Shang, D., Tan, Z., Wang, Y., Le Breton, M., Lou, S., Tang, M., Wu, Y., Zhu, W., Zheng, J., Zeng, L., Hallquist, M., Hu, M., and Zhang, Y.: Efficient $\mathrm{N}_{2} \mathrm{O}_{5}$ uptake and $\mathrm{NO}_{3}$ oxidation in the outflow of urban Beijing, Atmos. Chem. Phys., 18, 9705-9721, https://doi.org/10.5194/acp18-9705-2018, 2018b.

Wang, J., Zhang, X., Guo, J., Wang, Z., and Zhang, M.: Observation of nitrous acid (HONO) in Beijing, China: Seasonal variation, nocturnal formation and daytime budget, Sci. Total Environ., 587, 350-359, 2017.

Wang, S. W., Zhang, Q., Streets, D. G., He, K. B., Martin, R. V., Lamsal, L. N., Chen, D., Lei, Y., and Lu, Z.: Growth in $\mathrm{NO}_{x}$ emissions from power plants in China: bottom-up estimates and satellite observations, Atmos. Chem. Phys., 12, 4429-4447, https://doi.org/10.5194/acp-12-4429-2012, 2012.

Wang, Y., Zhou, L., Wang, M., and Zheng, X.: Trends of atmospheric methane in Beijing, Chemosphere, 3, 65-71, 2001.
Wen, L., Chen, J., Yang, L., Wang, X., Xu, C., Sui, X., Yao, L., Zhu, Y., Zhang, J., and Zhu, T.: Enhanced formation of fine particulate nitrate at a rural site on the North China Plain in summer: The important roles of ammonia and ozone, Atmos. Environ., 101, 294-302, 2015.

Wu, R., Li, J., Hao, Y., Li, Y., Zeng, L., and Xie, S.: Evolution process and sources of ambient volatile organic compounds during a severe haze event in Beijing, China, Sci. Total Environ., 560, 62-72, 2016.

Xiao, H., Xie, L., Long, A., Ye, F., Pan, Y., Li, D., Long, Z., Chen, L., Xiao, H., and Liu, C.: Use of isotopic compositions of nitrate in TSP to identify sources and chemistry in South China Sea, Atmos. Environ., 109, 70-78, 2015.

Xu, X., Zhao, W., Zhang, Q., Wang, S., Fang, B., Chen, W., Venables, D. S., Wang, X., Pu, W., Wang, X., Gao, X., and Zhang, W.: Optical properties of atmospheric fine particles near Beijing during the HOPE-J3A campaign, Atmos. Chem. Phys., 16, 6421-6439, https://doi.org/10.5194/acp-16-6421-2016, 2016.

Ye, P., Xie, Z., Yu, J., and Kang, H.: Spatial distribution of methanesulphonic acid in the Arctic aerosol collected during the Chinese Arctic Research Expedition, Atmosphere, 6, 699-712, 2015.

Yu, Z. and Elliott, E. M.: Novel Method for Nitrogen Isotopic Analysis of Soil-Emitted Nitric Oxide, Environ. Sci. Technol., 51, 6268-6278, https://doi.org/10.1021/acs.est.7b00592, 2017.

Zhang, J., Chen, Z., Lu, Y., Gui, H., Liu, J., Liu, W., Wang, J., Yu, T., Cheng, Y., and Chen, Y.: Characteristics of aerosol size distribution and vertical backscattering coefficient profile during 2014 APEC in Beijing, Atmos. Environ., 148, 30-41, 2017.

Zhang, Q., Streets, D. G., He, K., Wang, Y., Richter, A., Burrows, J. P., Uno, I., Jang, C. J., Chen, D., Yao, Z., and Lei, Y.: NOx emission trends for China, 1995-2004: The view from the ground and the view from space, J. Geophys. Res., 112, D22306, https://doi.org/10.1029/2007JD008684, 2007.

Zhang, Y., Liu, X., Fangmeier, A., Goulding, K. T. W., and Zhang, F.: Nitrogen inputs and isotopes in precipitation in the North China Plain, Atmos. Environ., 42, 1436-1448, 2008.

Zheng, B., Zhang, Q., Zhang, Y., He, K. B., Wang, K., Zheng, G. J., Duan, F. K., Ma, Y. L., and Kimoto, T.: Heterogeneous chemistry: a mechanism missing in current models to explain secondary inorganic aerosol formation during the January 2013 haze episode in North China, Atmos. Chem. Phys., 15, 2031-2049, https://doi.org/10.5194/acp-15-2031-2015, 2015.

Zheng, G. J., Duan, F. K., Su, H., Ma, Y. L., Cheng, Y., Zheng, B., Zhang, Q., Huang, T., Kimoto, T., Chang, D., Pöschl, U., Cheng, Y. F., and He, K. B.: Exploring the severe winter haze in Beijing: the impact of synoptic weather, regional transport and heterogeneous reactions, Atmos. Chem. Phys., 15, 2969-2983, https://doi.org/10.5194/acp-15-2969-2015, 2015. 